UNIVERSIDADE DE BRASÍLIA

Centro de Excelência em Turismo

Curso de Especialização em Docência e Pesquisa em Turismo e

Hospitalidade

\title{
REPRESENTAÇÃO SOCIAL DOS MOTÉIS PARA OS BRASILEIROS
}

CARLA BAYLÃO DE CARVALHO

Orientadora: Prof ${ }^{\text {a }}$ Dra. Deis Elucy Siqueira

Monografia apresentada ao Centro de Excelência em Turismo da Universidade de Brasília como requisito parcial para a obtenção do Certificado de Especialista em Docência e Pesquisa em Turismo e Hospitalidade.

Brasília, dezembro de 2003 
UNIVERSIDADE DE BRASÍLIA

Centro de Excelência em Turismo

Curso de Especialização em Docência e Pesquisa em Turismo e Hospitalidade

\section{REPRESENTAÇÃO SOCIAL DOS MOTÉIS PARA OS BRASILEIROS}

CARLA BAYLÃO DE CARVALHO

Banca Examinadora

Orientadora: Profa. Dra. Deis Elucy Siqueira

Membro: Profa. Dra. Maria Salete kern Machado

Brasília, 04 de dezembro de 2003 


\title{
CARLA BAYLÃO DE CARAVLHO
}

\section{REPRESENTAÇÃO SOCIAL DOS MOTÉIS PARA OS BRASILEIROS}

\author{
Comissão Avaliadora
}

Orientadora: Profa. Dra. Deis Elucy Siqueira

Membro: Profa. Dra. Maria Salete kern Machado

Brasília, 04 de dezembro de 2003 
Dedico este trabalho a todos que gostam de inovar e não se furtam aos desafios de temas novos e instigantes. 


\section{AGRADECIMENTOS}

À minha super família sempre tão compreensiva, carinhosa e paciente nos momentos de alegria e de cansaço, de bom e de mau humor.

Aos amigos e companheiros de curso, em especial Osney, Margarida, Ilka, pelo companheirismo, carinho e alegria; as amigas e companheiras de estrada Ana Paula, Karina e minha irmã Sônia, sempre tão protetora; estrada nenhuma se trilha sozinho, os amigos são força, são alegria, são energia para continuar sempre em frente.

E como não poderia deixar de ser, meu agradecimento especial a profa. Deis Siqueira, Tânia Montoro e Profa. Thereza Negrão pela confiança, credibilidade e paciência com as nossas dificuldades de tempo, de datas e tudo o mais.

Obrigada!! 
“Pros erros há perdão; pros fracassos, chance: pros amores impossíveis,

tempo.

De nada adianta cerrar o coração vazio ou economizar a alma. Um romance cujo fim é instantâneo ou indolor não e romance. Não deixe que a saudade sufoque, que a rotina acomode, que o medo impeça de tentar...” Luis Fernando Veríssimo 


\section{RESUMO}

Esse estudo traz a luz à discussão de um tema polêmico, os motéis brasileiros e discute por um viés também bastante polêmico, que é a Representação Social. Faz um histórico do surgimento dos motéis nos EUA e como se expandiu no mundo e no Brasil. Discute também, a transformação do conceito tradicional de motéis que passaram de hotéis simples de beira de estrada conhecido nos EUA e Europa, para locais destinados a encontros reservados, como acontece somente aqui no Brasil e o que levou a essa mudança. Discute também a questão da representação social dos motéis para os brasileiros.

Através da pesquisa realizada junto a homens e mulheres adultos percebeu-se que os motéis, para os brasileiros, são vistos como local de lazer e divertimento no campo da sexualidade, sendo que a sua representação social está ancorada numa suspensão do cotidiano, na quebra de rotina da vida em família.

\section{PALAVRAS-CHAVE:}

Motel, representação social, casa, sexualidade. 


\begin{abstract}
This study brings to the light the discussion of a polemic theme, the Brazilian motels, and discusses throw a polemic point, that is the social representation. Makes a historical description of motels arising in the USA and how expanded to the world and in Brazil. Discuss also the transformation of the traditional concept of motels that beginning from simple hotels on the roads very knowed in USA and Europe to reserved places to reserved meetings, that happens in Brazil, ad what brings to this change. Discuss also the question of social representation of motels to Brazilians.

Trough of the research made with men's and women, perceived that motels to the Brazilians are seen like a pleasure and diversion in a sexuality field, and the social representation are refuged in a break of routine in the familiar life.
\end{abstract}

\title{
KEY WORDS
}

Motel, social representation, house, sexuality 
SUMÁRIO

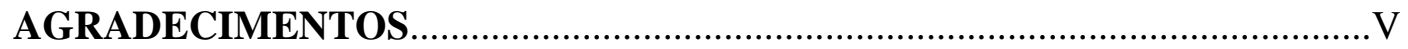

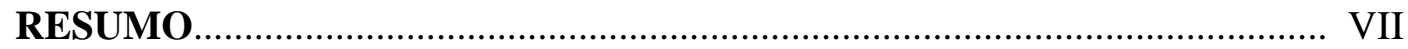

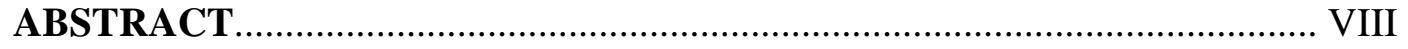

LISTAS DE GRÁFICOS......................................................................... XI

LISTAS DE FIGURAS............................................................................. XII

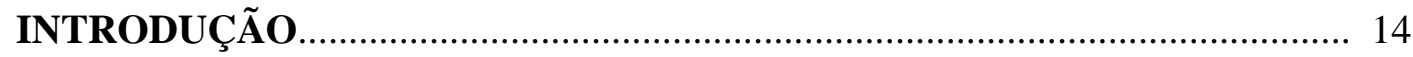

\section{CAPÍTULO I}

MOTEL: DE MEIO DE HOSPEDAGEM PARA VIAJANTES A LOCAL

PARA ENCONTROS RESERVADOS.............................................................16

\section{CAPÍTULO II}

SIGNIFICADO E RESSIGNIFICAÇÃO: A FAMÍLIA, O GÊNERO, A SEXUALIDADE, OS ESPAÇOS DA CASA E DA RUA.

21 Do Brasil Colônia a modernidade: a construção do "ser brasileiro"

2.3. Representação Social: a construção identitária a partir do núcleo familiar no Brasil

\section{CAPÍTULO III}

REPRESENTAÇÃO SOCIAL DOS MOTÉIS: RESULTADO DA PESQUSA DE CAMPO

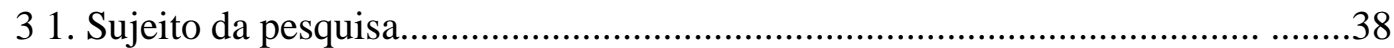

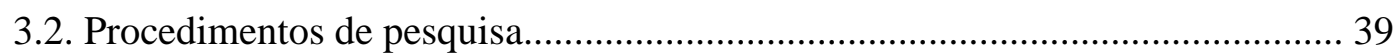




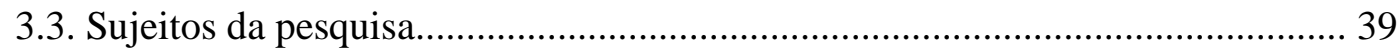

3.3.1. Sujeito Masculino............................................................................... 39

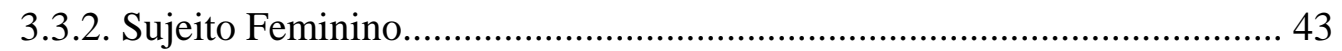

3.3.3. Análise comparativa dos sujeitos.................................................................. 46

3.4. Hábitos dos sujeitos em relação aos motéis........................................................47

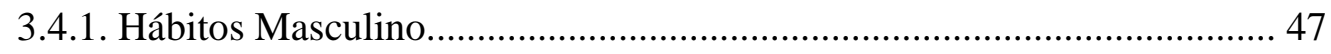

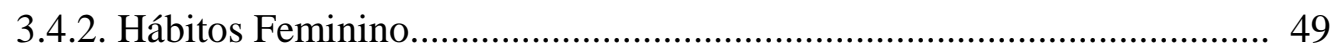

3.4.3. Análise comparativa dos hábitos dos sujeitos....................................... 52

3.5. Representação social dos motéis para os sujeitos ........................................... 53

3.5.1. Representação social para o sujeito masculino....................................... 53

3.5.2. Representação social para sujeito feminino........................................... 62

3.5.3. Análise comparativa da representação social para os sujeitos................. 71

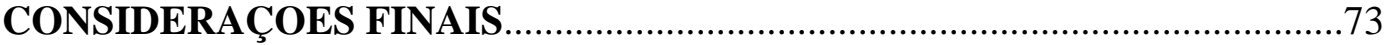

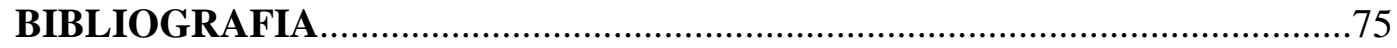




\section{LISTAS DE GRÁFICOS}

Gráfico 01 Faixa Etária - Sujeito Masculino...............................................39

Gráfico 02 Estado Civil - Sujeito Masculino...............................................40

Gráfico 03 Formação Educacional - Sujeito Masculino............................... 41

Gráfico 04 Ocupação Profissional - Sujeito Masculino................................41

Gráfico 05 Renda Salarial - Sujeito Masculino.........................................42

Gráfico 06 Faixa Etária - Sujeito Feminino................................................43

Gráfico 07 Estado Civil - Sujeito Feminino.................................................43

Gráfico 08 Formação Educacional - Sujeito Feminino..................................44

Gráfico 09 Ocupação Profissional - Sujeito Feminino..................................44

Gráfico 10 Renda Salarial - Sujeito Feminino ........................................... 45

Gráfico 11 Hábito de Freqüentar Motel - Sujeito Masculino.........................47

Gráfico 12 Frequência nos Motéis - Sujeito Masculino...............................47

Gráfico 13 Dias da Semana que Frequenta Motel - Sujeito Masculino...........48

Gráfico 14 Horário que Freqüenta Motel - Sujeito Masculino...................... 48

Gráfico 15 Hábito de Freqüentar Motel - Sujeito Feminino.......................... 49

Gráfico 16 Frequência nos Motéis - Sujeito Feminino................................. 50

Gráfico 17 Dias da Semana que Freqüenta Motel....................................... 50

Gráfico 18 Horário que Freqüenta Motel - Sujeito Feminino....................... 51

Gráfico 19 O que chama a atenção no Motel - Sujeito Masculino................. 53

Gráfico 20 Significado dos Motéis - Sujeito Masculino................................ 54

Gráfico 21 Permissão para Filho(a) Levar Namorado(a) para Dormir em Casa

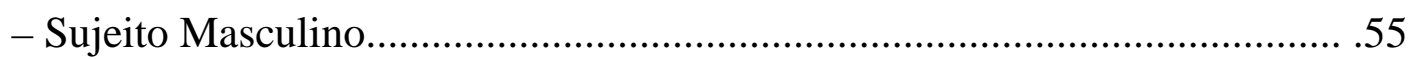

Gráfico 22 O que Chama a Atenção no Motéis - sujeito Feminino............... .62

Gráfico 23 Significado dos Motéis - Sujeito Feminino................................ 63

Gráfico 24 Permissão para Filho(a) Levar Namorado(a) para Dormir em Casa

- Sujeito Feminino .64 


\section{LISTAS DE FIGURAS}

Figure 01 Sala de Estar Admiral Inn Motel - Canadá.................................................17

Figura 02 Suíte Máster - Fly Motel - ES.................................................................20

Figura 03 Suíte Romain Ville Motel - SP..................................20 


\section{INTRODUÇÃO}

Dentre os meios de hospedagem existentes no Brasil, o motel é o que sofre maior pré-conceito, uma vez que, aqui no Brasil, houve uma mudança radical no seu perfil, mudando de hotel de beira de estrada, voltado para o turismo rodoviário, para empreendimento destinado a encontros reservados.

Esse perfil dos motéis brasileiros faz parte de um contexto cultural, que vem desde a formação do povo brasileiro e que está relacionada à identidade e o forte erotismo presente no dia-a-dia desse povo. As pesquisas a respeito dos motéis sejam do ponto de vista operacional ou dos aspectos sócio-antropológicos que envolvem essa transformação são poucas e ainda insipientes.

Em função desse cenário, optou-se por desenvolver um estudo que pudesse levar ao entendimento da transformação do perfil do segmento motel a partir da representação social que homens e mulheres brasileiros fazem do ambiente do motel.

A presente monografia está estruturada em três capítulos distribuídos de forma a permitir o aprofundamento na história dos motéis e a transformação desses ao longo do tempo, na formação do povo brasileiro e a representação social da casa e do motel, e o resultado da pesquisa de campo, que aponta a representação social a respeito dos motéis.

O Capítulo I conta à história dos motéis, seu surgimento nos Estados Unidos, quais os fatores que geraram esse tipo de meios de hospedagem, a confusão conceitual, sua expansão para outros continentes, como Europa e finalmente, o motel no Brasil.

O capítulo II, dividido em dois aspectos: a formação cultural, a família e sexualidade, a influência religiosa no comportamento do brasileiro. Trata-se de um interessante mergulho sócio-histórico-antropológico que permite entender alguns aspectos do porque os motéis no Brasil apresentam essa particularidade que não se vê no restante do mundo. A representação social é um dos elementos fundamentais para se entender este processo. 
Portanto, o Capítulo III apresenta os resultados da pesquisa de campo que buscou identificar a representação social que os brasileiros tem dos motéis. A análise dos resultados foi dividida entre: Representação Social do Sujeito Masculino, Representação Social do Sujeito Feminino e Análise Comparativa da Representação Social dos Sujeitos.

Nas considerações finais, a comprovação das hipóteses permitiu sugerir caminhos que poderão contribuir para o aprofundamento do tema em questão. Destacando-se ainda a importância deste estudo em termos de contribuição a uma temática tão pouco investigada e refletida no Brasil. 


\section{CAPÍTULO I}

\section{MOTÉL: DE MEIO DE HOSPEDAGEM PARA VIAJANTES RODOVIÁRIOS A LOCAL PARA ENCONTROS RESERVADOS}

Os motéis, ou motor hotels ${ }^{1}$, termo usado pela primeira vez em 1926 na Califórnia, surgiram nos EUA, no princípio da década de 20 do séc $\mathrm{XX}$, com a expansão do transporte individual em automóvel, e ganhou força na década de 50, em decorrência do desenvolvimento automobilístico e tecnológico no pós Segunda Guerra Mundial. Em função desse fluxo nas rodovias, surgiu a necessidade de locais para repouso próximos às estradas, para que os viajantes não tivessem que entrar nas cidades o que, muitas vezes, resultava em horas perdidas para achar um hotel, bem como para sair da cidade.

Esse desenvolvimento do setor moteleiro se deu, também, em função de uma parcela da população que apresentava um novo perfil, uma necessidade de ficar à vontade e não se submeter ao luxo e ao glamour da época áurea do setor hoteleiro, como afirma LATTIN ${ }^{2}$ :

cada vez más, en aquel tiempo las familias norteamericanas viajaban como unidades $y$ el medio de transporte era el automóvil. Los hábitos, los gustos y los deseos del público automovilista habían sufrido cambios

\footnotetext{
${ }^{1}$ Entende-se que o termo motel é a contração de motor hotel, portanto para essa monografia, são considerado sinônimos, adotando a posição de DOMINGUES mencionada detalhadamente nesse mesmo capítulo.

${ }^{2}$ LATTIN, Gerald W. Administración moderna de hoteles y moteles. México: Trillas, 1975 (reimp.2000:23-5)
} 
considerables. El modo de vida norteamericano había adoptado una nueva nota de informalidad. Repentinamente, hubo modo de eliminar la ropa formal, las presentaciones en los vestíbulos de los hoteles, las propinas y los problemas de estacionamiento....

Tal colocação só vem reforçar o caráter de um tipo de empreendimento voltado para o turismo rodoviário, a negócios ou familiar e com serviços simplificados nos motéis, como mostra a figura 1.

Figura 1: Sala de Estar - Admiral Inn Motel - Canadá

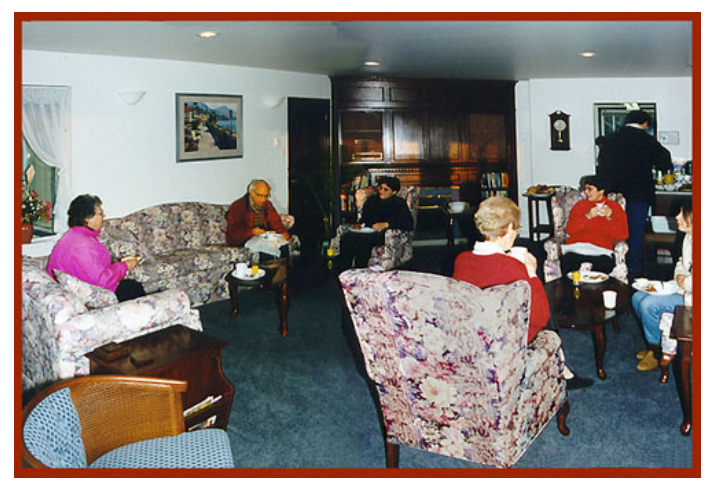

Fonte: www. Admiralinnmotel.com

Este setor apresentou um crescimento vertiginoso, segundo Domingues ${ }^{3}: \mathrm{em}$ 1925 havia já cerca de 10.000 motéis nos EUA e em 1961 o número desses estabelecimentos havia subido para cerca de 60.000. O excesso de oferta de alojamentos desta natureza, sobretudo nos EUA, veio criar problemas de sobrevivência para muitos deles, que vieram a se transformar em clubes de campo, empreendimentos imobiliários, centros de diversões, clínicas, casas de repouso, etc. LATTIN $^{4}$ apresenta uma estatística de crescimento de 0,9\% até 1929; 3,6\% na década de 30; $16,3 \%$ na década de $40 ; 50,7 \%$ na década de 50 e 23,5\% na década de 60.

\footnotetext{
${ }^{3}$ DOMINGUES, Celestino M. Prontuário turístico. 2.ed. Lisboa, INFT, 1997.

${ }^{4}$ Op.cit.
} 
Assim como o percentual em empreendimentos cresceu progressivamente, da mesma forma que ocorreu o aumento do número de leitos. Enquanto no início de 1950 os empreendimentos tinham no máximo cinqüenta unidades habitacionais, dez anos depois, os motéis apresentavam estrutura com oitenta a cem UHs.

Em relação ao modo de administração, os primeiros empreendimentos do segmento eram marcadamente de administração familiar. Posteriormente o crescimento do setor foi acompanhado pela profissionalização da gestão de motéis e a entrada marcante das cadeias moteleiras, tais como: City Squire Motor Hotel, Holiday Inn, entre outros.

Esse período de 1950-1960 foi uma época de muita confusão conceitual, na qual a discussão sobre a diferença entre hotel, motel e motor hotel foi polêmica ${ }^{5}$. Essa era uma dúvida constante até mesmo entre os proprietários, pois alguns baseavam a diferença no tipo de estrutura arquitetônica - vertical para hotéis e horizontal para motéis e motor hotels; porém logo os motéis expandiram-se e também adotaram estruturas verticais. Nesse contexto surgiu a questão das garagens internas, próximas aos apartamentos para os motéis e motor hotels. E esse mesmo padrão de estrutura arquitetônica também foi adotado por alguns hotéis. Posteriormente, os estabelecimentos que continham mais de quarenta UHs passaram a ser definidos como motéis e aqueles que continham menos de quarenta unidades foram chamados de motor hotels. Outra característica comum aos motéis e motor hotels é a localização ao redor da cidade, às margens das rodovias e nos subúrbios das cidades.

Para DOMINGUES ${ }^{6}$, motel é a contração de motor hotel, portanto ambos são uma coisa só, ou seja:

estabelecimento hoteleiro cuja principal característica reside no fato de se projetar horizontalmente no espaço, distribuindo as acomodações por unidades autônomas, correspondendo a cada uma a área destinada ao parqueamento de um automóvel ligeiro, e

\footnotetext{
${ }^{5}$ LATTIN, op.cit. (2000: 69)

${ }^{6}$ op. cit. (1997)
} 
apoiado por serviços localizados num núcleo central (...) situam-se predominantemente na periferia de grandes cidades, em áreas rurais e junto de estradas com intensa densidade de tráfego, bem como em locais de veraneio.

A Europa teve seu auge no crescimento moteleiro na década de 70 e com forte apoio de companhias petroleiras ou proprietárias de postos de gasolina, como a ESSO que construiu quatorze motéis em países como Suécia, Dinamarca, Alemanha, Itália e Inglaterra. LATTIN $^{7}$ achava difícil o crescimento dos motéis no restante do mundo em função da falta de estradas, ele presumia que, quando as estradas estivessem em boas condições, os motéis já seriam um conceito obsoleto.

A dificuldade de se localizar estudos sobre os motéis no Brasil leva a uma enorme imprecisão sobre a entrada desse tipo de empreendimento no país. Sabe-se apenas que os primeiros motéis brasileiros tinham a mesma finalidade que os motéis americanos e europeus, ou seja, eram hotéis horizontais, com serviços simples e rápidos, próximos às rodovias, com o objetivo de atender o viajante rodoviário. Porém, com o passar do tempo, no Brasil, o perfil da clientela mudou completamente. Esse meio de hospedagem passou a ser utilizado por casais homo e heterossexuais para encontros reservados.

Essa nova realidade gerou no Brasil uma modalidade particular de motéis, sui generis, dificilmente encontrada em outros países do mundo. Sua estrutura física passou por mudanças estratégicas radicais, como UHs com garagens internas privativas com portões fechados, apartamentos todos com cama de casal e decoração cada vez mais suntuosa e estimulante, com ambientes variados, como: sauna, piscina e boate particular, corredor de serviço isolado, boquetas passa pratos e/ou outros cômodos que proporcionam a prática de serviços sem nenhum contato direto entre funcionários e clientes, como se percebe na UH de motel brasileiro mostrado Figura 2 e 3.

${ }^{7}$ Op.cit. (2000) 
Figura 2: Suíte Fly Motel/ES

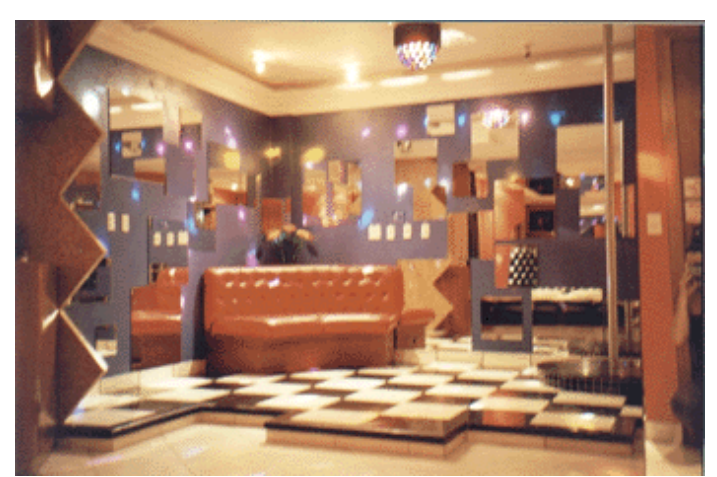

www.flymotel.com.br
Figura 3: Suíte Romain Ville Motel/SP

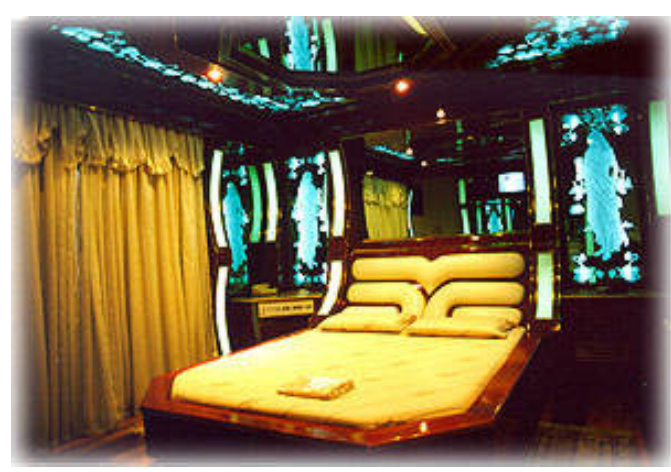

www.romainvillemotel.com.br

Houve outras mudanças: as tradicionais FNRH (ficha nacional de registro de hóspedes) ou qualquer tipo de ficha deixaram de ser preenchidas; e o período de estada foi reduzido para duas a quatro horas em média.

Todas essas mudanças tiveram origem em fatores sócio-culturais, a partir da formação do povo brasileiro, com suas raízes no Brasil-Colônia, gerando também uma nova representação social desses ambientes na relação entre o público-privado, rua-casa, familiar/respeito e privativo/liberdade. 


\section{CAPÍTULO II}

\section{SIGNIFCADO E RESSIGNIFICAÇÃO: A FAMÍLIA, O GÊNERO, A SEXUALIDADE E OS ESPAÇOS DO LAR E DA RUA}

\subsection{Do Brasil colônia a modernidade: a Construção do "ser brasileiro"}

Falar em motéis, muitas vezes, é falar de algo pecaminoso, quase proibido, e provocar a surpresa de uns ou a desconfiança de outros. Porém, os motéis são considerados meios de hospedagem do tipo extra-hoteleiro e representam um segmento bastante lucrativo; segundo o Centro de Apoio Hoteleiro (CAH), o objetivo maior é obter resultados financeiros através da locação de espaço (apartamentos), com segurança, discrição, higiene, conforto e condições para a realização das fantasias dos casais que procuram esses serviços, ou de clientes comuns que optam por esse tipo de hospedagem ${ }^{9}$

Tais alterações, como não podia deixar de ser, geraram rotinas diferenciadas, pois os clientes não querem descer dos carros nem para preencher ficha de entrada, nem para pagar. Em função disso, a recepção, estrategicamente, passou a se localizar logo na entrada, fechada, sendo que os clientes não precisam sair de dentro dos carros, assim tudo se resolve e pouco se vê.

Especificamente em governança, as mudanças ocorreram na operacionalização da arrumação de UH. Enquanto nos hotéis o processo de higienização de UH classifica-se em: Limpeza de UH Ocupado, Saída, Revisão e Limpeza Periódica, nos motéis, esse mesmo processo classifica-se em limpeza Rotativa, Rotineira e Periódica, segundo o Centro de Apoio Hoteleiro, porém tanto a

9 Centro de Apoio Hoteleiro. Motel organize e administre. Campinas/SP, Ipê, 2000. 
limpeza rotativa, quanto à rotineira, equivale ou deveriam ser equivalentes à limpeza de saída, ou seja, higienização para ocupação de novo hóspede.

Dentro do processo de assepsia, seja a limpeza Rotativa, realizada nos períodos de maior movimento ou a Rotineira, mais detalhada realizada nos períodos de menor movimento, necessita de uma higienização profunda, pois nenhum resquício deve ficar do último ocupante para o próximo, bem como todos os germes e bactérias devem ser eliminados para que a saúde e segurança dos clientes sejam colocadas em risco.

Segundo Felipe Foppa ${ }^{10}$, a região da grande Goiânia, possui cerca de setenta motéis que apresentam uma rotatividade de sete a nove ocupações/dia, nos dias de maior movimento, feriados e finais de semana, para uma população total de 1.090.581 habitantes, sendo 659.940 jovens e adultos na faixa dos 15 aos 59 anos, segundo dados do IBGE, em 01/08/00. Índice esse, que referenda o gosto e a alta procura do povo goiano por esse tipo de estabelecimento, bem como, serve de alerta para os proprietários e gerentes de motéis se preocuparem com a qualidade dos serviços prestados em seus empreendimentos, principalmente nos itens de elevada importância para os clientes.

Essa transformação do motel no Brasil tem muito a ver com o comportamento, o estilo, o jeito de ser do brasileiro, a miscigenação cultural proveniente da construção da identidade desse povo que teve como base inicialmente os índios e portugueses seguidos pelos negros africanos.

ROMANELL ${ }^{11}$ em seu artigo: Eva Tupinambá mostra claramente como os hábitos indígenas escandalizaram os portugueses. Com seu jeito descontraído, os índios viviam nus e levavam uma vida tranqüila em função da subsistência e não do acúmulo de riquezas. Sexualmente eram bastante liberais, os esposos, quando se cansavam de suas esposas, costumavam dá-las de presente a outro homem; a poligamia era permitida entre os caciques e grandes guerreiros; as moças podiam manter relações com rapazes e com aventureiros europeus sem serem desonradas; os

\footnotetext{
${ }^{10}$ FOPPA, Felipe. Proprietário e gerente dos motéis Chalé e Sedução - Goiânia/GO

${ }^{11}$ ROMANELLI, Ronaldo. Eva Tupinambá. In DEL PRIORI, Mary (org) e BASSANEZI, Carla (coord de textos) História das mulheres no Brasil. São Paulo: Contexto, 1997.

${ }^{12}$ VAINFAS, Ronaldo. Moralidade brasílicas: deleites sexuais e linguagem erótica na sociedade escravista._In SOUZA, Laura de Mello e.(org) História da vida privada no Brasil 1: cotidiano e vida priva na América Portuguesa. São Paulo: Cia. Das Letras, 1997. (p.119)
} 
'pecados da carne' eram praticados de todas as formas. Em locais seguros, onde se sentiam seguros ... sempre a mulher vai adiante e o marido atrás, porque são ciosos e querem sempre ver as mulheres ${ }^{12}$, o brasileiro de hoje, assim como o indígena é famoso por prestigiar o andar, o requebro, as nádegas das brasileiras.

Apesar do espanto e da reprovação, os europeus fizeram uso desses costumes em proveito próprio. Aproveitaram-se da inocência dos indígenas, que acreditaram serem os europeus deuses saindo das águas, para explorá-los de todas as formas. As índias, que podem ser consideradas mães e matrizes do povo brasileiro, foram usadas sexualmente pelo fato de serem belas e liberais nos seus hábitos, e também em decorrência da escassez de mulheres brancas, o que deu início à primeira geração de mestiços.

A moralidade pregada pela proposta dos religiosos e a moral portuguesa em função do perfil dos índios e sua dificuldade em entender tais costumes dos portugueses, bem como a moralidade, ou falta dela, por parte dos próprios colonizadores era duvidosa, bastante partidarista e dúbia. A maioria dos portugueses que aqui chegaram do século XVI ao XVIII foi banida de Portugal como punição por crimes cometidos.

Em outras palavras, o caráter moral de nossos colonizadores não era tão reto como pregava a moral cristã, porém estes tentavam reproduzir os costumes e a moral européia na colônia, o que esbarrava na falta de mulheres brancas para casar. Já as índias e as negras escravas não eram mulheres para casamento e, sim, para tratos ilícitos, como se dizia na época.

Na moral européia existiam dois tipos de mulheres: a pura e casta, a qual deveria ser respeitada, feita para casar; e as mulheres para o uso, o divertimento, a paixão e o deleite sexual. As casadoiras resumiam-se em mulheres brancas criadas com total desvelo, normalmente por famílias abastadas. As outras eram basicamente as índias, negras, mestiças e mulheres brancas pobres obrigadas a se prostituírem para o próprio sustento. Esse duplo padrão de moralidade acabou por determinar uma aculturação de mão dupla, como afirma VAINFAS ${ }^{13}$ : A sexualidade pluriétnica

\footnotetext{
13. Op.cit. (1997:231)
} 
determinada pelo estilo da colonização portuguesa andou, portanto, de braço dado com o processo de aculturação de mão dupla deflagrado no século XVI.

As negras entraram nesse processo de mestiçagem de um modo irreversível, os casamentos entre os negros eram raridade na colônia, porém no intercurso sexual os europeus usaram a seu bel-prazer tanto os corpos de negras quanto de negros, independente de sua idade e isso foi determinando um número cada vez maior de filhos ilegítimos de negras com pais brancos.

Foi desse cenário de contradições, exploração, abuso e ilegitimidade que surgiu o verdadeiro brasileiro, o mestiço, homens e mulheres inicialmente sem nação, pois não eram verdadeiramente brancos e nem índios, não eram filhos de pais índios ou eram escravos despojados de qualquer direito.

Esse brasileiro que, aos poucos, foi se tornando maioria, cada vez mais miscigenada, era capaz de andar no mato, caçar e pescar como o índio, vestir-se e sentar-se à mesa como o branco ou cultuar os orixás como o negro, marcando uma flexibilidade tipicamente brasileira. RIBEIRO ${ }^{14}$ fala desse povo brasileiro como um povo novo de raça única, singular. Esse jeito brasileiro é novo porque surge como uma etnia nacional, diferenciada culturalmente de suas matrizes formadoras, fortemente mestiçada, dinamizada por uma cultura sincrética e singularizada pela redefinição de traços culturais delas oriundas.

O brasileiro propriamente dito, tem um pouco de tudo isso, herdou uma cultura tão rica e miscigenada, que se tornou único, singular. É faceiro como eram faceiros os africanos, tem verdadeira atração pelas ancas femininas como tinham os índios que gostavam de ver suas mulheres à frente caminhando e como os portugueses que ficavam fascinados pelas ancas escondidas das negras de peitos nus. Sobre esse duplo moralismo sexual afirma RIBEIRO :

o que caracteriza o português de ontem e o brasileiro de classe dominante de hoje é a duplicidade de seus padrões de relação sexual: um, para as relações dentro de seu círculo social, e outro, aposto, para com a

\footnotetext{
${ }^{14}$ RIBEIRO, Darcy. O povo brasileiro: evolução e o sentido do Brasil. São Paulo: Companhia das Letras, 1995, (p.91).
} 
gente de camadas mais pobres. Nesse caso, se particulariza, pela desenvoltura no estabelecimento de relações sexuais do homem com a mulher de condição social inferior, movida pelo puro interesse sexual, geralmente despido de qualquer vínculo romântico”.

Nesse processo de formação, a família teve um papel muito importante, pois foi a base e o seio da formação sócio-cultural de seus membros, foi a partir do fogo doméstico e sua inter-relação com as peculiaridades raciais e religiosas que nasceu o brasileiro, com seus preconceitos onde dentro de casa se guarda o respeito e fora dela tudo pode.

Essa contradição nos valores e comportamento levou os religiosos inacianos a solicitarem que a corte enviasse mulheres brancas para que se pudesse impor o modelo de família portuguesa na colônia. Com o passar dos tempos e, em contrapartida ao concubinato, hábito corrente no Brasil Colônia, a família patriarcal e conservadora, aos poucos, foi se instituindo como forma de ascensão social e também pela influência da igreja nas famílias.

Com o passar do tempo, já na Belle Époque (1890-1920) com a participação cada vez maior das mulheres como força de trabalho, a organização da família fortificou-se junto com a necessidade de uma classe dirigente sólida com valores rígidos, os quais eram cobrados principalmente das mulheres.

A cobrança e a vigilância sobre a mulher, o seu comportamento pessoal e familiar, ainda é muito forte, tanto que a discussão do trabalho feminino era constantemente atrelada às questões sexuais como o adultério, a virgindade, o casamento e a prostituição, numa disciplinarização ferrenha do espaço e do tempo de trabalho e demais esferas da vida, como coloca SOIBET ${ }^{15}$, em seu artigo: Mulheres pobres e violência no Brasil urbano.

\footnotetext{
${ }^{15}$ SOIBET, Rachel. Mulheres pobres e violência no Brasil urbano. In: DEL PRIORI, MARY (ORG) e BASSANEZI, Carla (coord ${ }^{\mathrm{a}}$ de textos). História das mulheres no Brasil. São Paulo: Contexto, 1997.
} 
Até mesmo nos anos dourados (década de 50), apesar das mudanças no modo de vida, a questão da sexualidade e do casamento mantinha pontos comuns com os períodos anteriores. Com a moralidade favorecendo as escapadas extraconjugais masculinas, as mulheres continuaram a ser criadas educadas para serem, fundamentalmente, esposas e mães.

Tais valores foram contestados pelos jovens da década de 50 e 60 e acabou por deflagrar, principalmente no período de 1967 a 1971, o movimento feminista. As mulheres já não aceitavam mais serem tratadas como seres inferiores, desprovidos de desejos, de necessidades sexuais, de inferioridade no trabalho. MORIN ${ }^{16}$, diz que ... o movimento feminino se verá estimulado, ou mesmo às vezes desencadeado, pela onda de choque existencial-cultural, que põe em movimento a sede de mudar a vida desde já, pela forma como age a militância esquerdista, que lhe injeta sua agressiva virulência.

O casamento desde então, passou a se basear cada vez mais na escolha em função dos laços afetivos, o amor e a atração sexual, com igualdade entre os sexos. Não havia mais a obrigatoriedade de um casamento que não fosse o idealizado pelos pais a partir de interesses financeiros e pessoais como antigamente.

Mudaram também a durabilidade do casamento, enquanto que nos casamentos antigos, bem ou mal não se aceitava a idéia de separação, nesse novo padrão de casamento, as relações se tornaram cada vez mais efêmeras, ou seja, as pessoas se casavam pensando que, se a relação não der certo, se separariam. MORIN ${ }^{17}$ afirma que a linha de resistência da censura sexual recua cada vez mais; não se trata apenas da censura da imagem, do filme, da palavra escrita, que abandona suas linhas avançadas e sofre grande recuo por volta de 1968; trata-se da censura interior, aquela pela qual se proíbe o adultério, o coito, a relação sexual livre.

Esse processo irreversível deu origem a um novo modelo de família bem mais liberal, que segundo $\mathrm{CAMARGO}^{18}$ surge, assim, uma nova família, menos autoritária, mas mais democrática, em que as diferentes gerações dificilmente compartilham dos mesmos gostos e atividades. As roupas, por exemplo, já não têm

\footnotetext{
${ }^{16}$ Op. Cit. (1999:165)

${ }^{17}$ Op. Cit. (1999:166)

${ }^{18}$ CAMARGO, Luiz Octávio de Lima. Educação para o lazer. São Paulo: Moderna, 1998:53)
} 
mais a função de resguardar o pudor e a moral e, sim, de exibir e exaltar a beleza e a sensualidade. Porém a família ainda é resistente em abrir o ambiente familiar para todos os tipos de novidades, principalmente no campo sexual, levar um acompanhante para a casa dos pais é ainda uma questão que gera controvérsias em boa parte dos nos lares brasileiros.

O que se percebe no momento atual de relações incertas, buscas incessantes da realização sexual e amorosa, é um processo de sedução que se esgota logo nos primeiros encontros ou um encontro que se acaba logo após o orgasmo, fazendo com que as pessoas tenham um número cada vez maior de parceiros ao longo da vida. Tal situação não se restringe ao mundo adulto, pelo contrário, os jovens em suas tribos tendem a reproduzem esse mesmo comportamento.

Porém, tanto entre adultos como entre os jovens, tais acontecimentos, via de regra, se dão fora do espaço sagrado do lar, na busca por locais onde se pode ficar à vontade e soltar a libido. O espaço doméstico, cada vez mais reduzido com menos cômodos e menores tanto nos apartamentos, como em casas é um local de reclusão da família tradicional e dificilmente é aberto para os jovens trazerem suas namoradas e namorados, principalmente para as moças. Os pais, mesmo sabendo que a filha tem vida sexual ativa com seus namorados, ainda assim resistem, em boa medida, em permitir que essas os tragam para dentro de casa.

Essa é a realidade da família brasileira, ainda às voltas com tabus sexuais contra os quais os próprios pais de família de hoje se rebelaram em sua época e que hoje reproduzem junto aos seus filhos, ao mesmo tempo que, contraditoriamente, defendem a liberdade sexual de trocar de parceiros quando já não mais convier ficar juntos. Ainda sim, os pais não querem desmantelar a família em função dos filhos, por isso, muitas vezes optam pelos relacionamentos extraconjugais reproduzindo, ainda que inconscientemente, alguns dos valores do Brasil Colônia, como o duplo padrão moral no campo sexual.

Diante desse contexto, o motel brasileiro assumiu o papel das garçoniers dos anos dourados, ou seja, o local adequado para esses encontros extraconjugais ou o local adequado para a prática do sexo entre os jovens uma vez que a casa continua sendo o espaço aonde deve ser respeitados a moral e os bons costumes. 
Por um lado, em boa medida se trata de um local estigmatizado, como local de traição e de pecado, um lugar profano que se contrapõe ao espaço sagrado do lar. Por outro lado, o motel também é alvo de curiosidade, de mistério e de fantasias e povoa o imaginário de muitos brasileiros, homens e mulheres. 


\subsection{Representação Social: a construção identitária a partir do núcleo familiar} no Brasil.

Teste de bom senso:

Suponhamos que você venha a saber que seu marido a engana, mas tudo não passa de uma aventura banal, como há tantos na vida dos homens. Que faria você?

Uma violenta cena de ciúmes?

Fingiria ignorar tudo e esmerar-se-ia no cuidado pessoal para atraí-lo?

Deixaria a casa imediatamente?

Respostas:

A primeira resposta revela um temperamento incontrolado e com isso se arrisca a perder o marido, que, após uma dessas pequenas infidelidades, volta mais carinhoso com um certo remorso.

A segunda resposta é a mais acertada. Com isso atrairia novamente seu marido $e$ tudo se solucionaria inteligentemente.

A terceira resposta é a mais insensata. Qual mulher inteligente que deixa o marido só porque sabe de uma infidelidade? $O$ temperamento poligâmico do homem é uma verdade: portanto, e inútil combatê-lo. Tratase de um fato biológico que para ele não tem importância. (Jornal das Moças, 17, abr. 1952) BOSSANEZI ${ }^{19}$

${ }^{19}$ BOZANEZZI, Carla (org) História das mulheres no Brasil. São Paulo: Contexto, 1997. 
Essa era a idéia corrente, a qual demonstra claramente a representação social que se tinha do casamento, do homem e da mulher até a década de 60, do século XX, uma mulher voltada para o lar, para a família, dedicada ao espaço do lar, onde ela era a rainha e o marido o seu rei, que como tal tinha privilégios ancorados em fatores biológicos, que a ela era negado e que, além disso, deveria fechar os olhos sob pena de perder o marido e ainda ser responsabilizada como insensata e até mesmo incompetente por não saber segurar o próprio marido.

Nas revistas, nas propagandas, nos cafés e chás da tarde se difundiam, ainda mais, tais conselhos, considerados sábios pelo senso comum. A moralidade da época favorecia as escapadas extraconjugais masculinas, as mulheres deviam ser criadas para serem esposas e mães, como mostrado no teste de bom senso do Jornal das Moças, citado por acima.

\begin{abstract}
Segundo Duveen ${ }^{20}, \ldots o$ conhecimento é sempre produzido através da interação $e$ comunicação e sua expressão está sempre ligada aos interesses humanos que estão neles implicados. $O$ conhecimento emerge do mundo onde as pessoas se encontram $e$ interagem, do mundo onde os interesses humanos, necessidades e desejos encontram expressão, satisfação ou frustração.
\end{abstract}

Esses conselhos comuns nas revistas feministas e reproduzidos nas famílias e entre outros meios de comunicação, como diz Duveen, implicitamente estavam relacionados aos interesses humanos daquela época, ou seja, no intuito de combater as massas jovens que se rebelavam nos movimentos estudantis e iam contra os costumes e a moral pregadas pelos pais; repudiando os valores, as regras de comportamento desse universo cultural de castração e falso moralismo, nos quais estavam inseridos.

\footnotetext{
${ }^{20}$ DUVEEN, Gerard. In MOSCOVICI, Serge. Representações sociais: investigações em psicologia social. Editado em inglês por Gerard Duveen: traduzido do inglês por Pedrinho A Guareschi. Petrópolis/RJ: Vozes, 2003. p.9.
} 
Ainda na década de 60 o movimento de mão dupla, que pregava também a liberação sexual infiltrava-se cada vez mais na consciência do "ser mulher" modificando substancialmente a visão de feminilidade, bem como da maternidade. O casamento já não é mais uma condição de sobrevivência sine qua non, como afirma DEL PRIORI ${ }^{21}$ o tabu do divórcio acabou, as famílias monoparentais se multiplicam e os jovens não fazem questão de casar para ter filhos. Vive-se um novo tempo, de valores contrários, percebe-se a construção de uma nova representação social da mulher, não mais a dona de casa, ciosa de ser deveres matrimoniais, mas a mulher trabalhadora, que vai a luta para conquistar o seu espaço no mercado de trabalho e a tão falada igualdade apregoada pelo movimento feminista. A conquista da autonomia profissional, a evolução dos modelos familiares e o controle da procriação transformaram sua imagem e situação social, como afirma DEL PRIORI ${ }^{22}$.

A década de 80 , século $\mathrm{XX}$, foi um período conturbado uma vez que os valores culturais, crenças e códigos comportamentais encontravam-se em choque, a mulher não mais só dona de casa, mas tendo que provar sua competência profissional, sua capacidade racional a todo instante, muitas vezes se masculiniza, adotando posturas de imitação do homem, comumente exemplificada por diversos autores, como as executivas de Wall Street, em Nova Iorque. DEL PRIORI ${ }^{23}$, diz que a questão maior para as brasileiras tem sido a de recusar as identidades importadas, preferindo investir na sua própria diferença.

Fica claro que é um período em que a representação social da mulher referese a um novo posicionamento na sociedade em que se insere, a sua percepção individual e coletiva é contrastante nesse período, pois ao mesmo tempo em que ela é agora uma mulher profissional, que ocupa espaço cada vez maior no mercado de trabalho, antigo domínio masculino; ela é também mãe, esposa e acaba por assumir dupla e às vezes tripla jornada de trabalho na rua e em casa. Pode-se dizer desse cenário que as representações sociais desse objeto social, ser mulher nos espaços da rua e da casa é o resultado de um encadeamento de fenômenos interativos, fruto do cotidiano da vida moderna que impõe uma nova postura à mulher, como também do homem.

\footnotetext{
${ }^{21}$ DEL PRIORI, Mary. Histórias do cotidiano. São Paulo: Contexto, 1997.

${ }^{22}$ Op. Cit. 2001:87.

${ }^{23}$ Op.Cit. 2001:87.
} 
Os papéis de homem e mulher são, em boa medida, hoje, intercambiáveis, É comum se encontrar homens que vivem sozinhos e cuidam de suas casas, lavam, passam, cozinham e cuidam dos filhos. Nos lares coabitados por homens e mulheres, os homens também tendem a assumem tarefas antes ditas femininas, porém com menor intensidade. Em relação à paternidade, como afirma DEL PRIORI ${ }^{24}$, o afeto substitui a autoridade. Mudanças no casamento e na própria família forçam muitos a assumir a paternidade social de filhos de outros homens ou a tornar-se 'pães'. Essa nova postura de maior afetividade, maior sensibilidade entre outras características também estão sendo exigidas dos homens no mercado profissional, denotando não só uma nova mulher, mas um novo homem, mais flexível, mais tolerante, menos dominador.

Não existe certo ou errado nesse cenário, o que existe é uma sociedade em transformação onde,... as mulheres reivindicam não mais serem reduzidas a uma só dimensão: elas querem ser ao mesmo tempo mães, trabalhadoras, cidadãs e sujeitos de seu lazer e prazer. E isso tudo com o estilo próprio com que cada uma constrói suas relações com o homem, como afirma DEL PRIORI ${ }^{25}$. Ou seja, independente de como seja, a construção de conhecimentos do senso comum, por parte do indivíduo, constitui um processo gerador de ações sociais a partir de visões de mundo, concepções ideológicas, crenças e valores culturais que estão presentes nas relações sociais da vida cotidiana, agora transformada por esse novo papel da mulher e do homem na sociedade.

Desde a década de 80 e 90, do século XX que o número de casamentos vem diminuindo e o do divórcio vem aumentando, um resultado dos novos papéis da mulher e do homem. A independência financeira mais acessível a ambas as partes, homem e mulher fazem com que a mulher agora tenha mais condições de garantir seu próprio sustento, o homem por sua vez fica mais livre pelo fato da mulher não mais depender exclusivamente dele para prover sua subsistência; já no campo da sexualidade, a mulher também ficou desobrigada, pois já não é uma questão somente de cumprir com os deveres matrimoniais, ela exige mais de seus parceiros, pois querem exercer o seu direito de ter prazer nas relações sexuais, de ter quantos

\footnotetext{
${ }^{24}$ Op.Cit. 2001:39

${ }^{25}$ Op. Cit. 2001:88
} 
parceiros desejar, dentro ou fora do casamento, e não esperar pelo casamento para obter esse prazer.

Nesse contexto, VICENT ${ }^{26}$ diz que: no casamento de outrora, o homem satisfazia seu desejo de mudar de parceira recorrendo à prostituição. Hoje, mesmo que a prostituição vá bem - e até muito bem -, as 'aventuras' no meio em que vive a pessoa podem se transformar em 'ligações', tanto da mulher quanto do homem. E nesses tempos em que os envolvimentos extraconjugais fascinam mais e mais uns e outros, reafirma-se aí a necessidade de um espaço físico que permita exercitar essa liberdade sexual.

As garçonieres financeiramente inviáveis são cada vez mais raras; já os motéis, práticos, baratos, sigilosos, privativos e misteriosos ocupam o espaço deixado pelas garçonieres como locais de encontros reservados, gerando aí, em boa medida, a idéia de lugar de pecado, profano, destinado à traição.

A questão da sexualidade no Brasil é marcada por um forte erotismo que, como coloca BARBOSA ${ }^{27}$ :

Parker (1991: 31-32) refere-se ao Brasil como, 'o maior país católico do mundo que revela a sua veia conservadora. Por outro lado, valorizam-se a sexualidade $e$ a transgressão da lei, da moral e do pecado'E ele ainda comenta que, 'não há explicação única para essa característica de cultuar o erotismo, mas a verdade é que o brasileiro é absolutamente fascinado pelo sexo'.

Esse é um outro campo da representação social dos brasileiros que vem marcado por uma série de tabus infiltrados nos núcleos familiares ocidentais pela

\footnotetext{
${ }^{26}$ PROST, Antoine e VINCENT, Gerard (orgs), tradução: Denise Bottmann. História da vida privada 5: da primeira Guerra a nossos dias. São Paulo: Companhia das Letras, 1992.

${ }^{27}$ BARBOSA, Sônia M. Costa. A representação da sexualidade e das doenças sexualmente transmissíveis segundo as idosas da Cidade de Olinda: Estudo de Caso na "Cais do Porto"ONG/OLINDA/PE. www.aya.org.ar/conresso2002. Acesso em: 08/10/2003.
} 
Igreja e pelas classes dominantes desde o Brasil-Colônia como já comentado anteriormente. Foi através das famílias que se reproduziu à ideologia esperada pelas classes dominantes, dando mais respeito e moralidade à relação sexual. Gerando uma forma de repressão sexual, uma vez que às esposas eram destinados o sexo contido e respeitoso e as outras mulheres eram destinados a liberdade, o prazer e a realização das fantasias masculinas.

Segundo VACCARI ${ }^{28}$, a questão da sexualidade é um campo carregado de condutas codificadas pelo senso comum num arcabouço de regras e comportamento onde, esses sentidos, valores, normas, interditos e permissões representam aquilo que se costuma chamar de 'repressão sexual'. Marcada por séculos e séculos de dominação masculina, essa repressão sexual faz parte de uma representação social da sexualidade que assume diferentes papéis para o ser homem e o ser mulher, na qual cada um assume conduta diferenciada como afirma VACCARI ${ }^{29}$ :

... homens e mulheres vivem a sexualidade de maneiras diferentes, socialmente determinadas, embora as diferenças pessoais também não devam ser esquecidas. É no campo, da sexualidade que as desigualdades sociais entre homens e mulheres surgem talvez com maior força, pois e o campo que liga direta entre os gêneros, que envolve, além de todas as questões da desigualdade, também as questões afetivas mais intensas.

O corpo hoje, principalmente o da mulher, é um objeto de desejo, exposto nas propagandas, nas novelas, na mídia de um modo geral, o que acaba por banaliza-lo sexualmente, ou seja, tanta exposição estimula constantemente a libido das pessoas. Isso fez surgir uma nova postura de culto ao corpo, uma exigência de estar o mais próximo possível da perfeição, o que se exige é, como bem coloca DEL PRIORI ${ }^{30}$,

\footnotetext{
${ }^{28}$ VACCARI, Vera. Mitos e tabus sobre a sexualidade. www.veravaccari.psc.br. Acesso em: 23/10/2003.

${ }^{29}$ Op. Cit. (2003)

${ }^{30}$ Op. Cit. (2001:100)
} 
uma estética esportiva voltada ao culto do corpo, fonte inesgotável de ansiedade e frustração, levou a melhor sobre a sensualidade imaginária e simbólica.

Não se pode esquecer aqui um dos papéis sociais do gênero, como afirma SEGATO $^{31}$ devemos separar ainda a disposição sexual da pessoa, ou seja, o que diz respeito ao seu comportamento sexual propriamente dito, e à sua tendência a assumir papéis sexuais ativos ou passivos em sua interação sexual. Por mais que se tenha avançado nas relações homem/mulher tanto nos espaços ditos de domínio público, de trabalho e de lazer, como nos espaços privados da moradia/lar ainda se percebe uma distância enorme entre tais conquistas e os objetivos almejados pelas mulheres,...ou seja, a exclusão e a inferioridade feminina ainda persistem, não apenas como categorias numéricas ou estatísticas, mas como fato sociológico, na medida em que o consenso como ideal regulador do discurso masculino não foi ainda rompido plenamente, como bem coloca BANDEIRA \& SIQUEIRA ${ }^{32}$.

Retoma-se aqui a questão dos valores contraditórios ainda presente no comportamento e no cotidiano dos brasileiros, esse ser apaixonada por futebol, praia, samba, carnaval, comida, festa, diversão e prazer e ainda não abre mão de sua fé misturada entre santos e orixás. Esse ser flexível, erotizado e afetivo com os amigos e parentes é também um ser conservador, como coloca DAMATTA ${ }^{33}$ em casa e no código da família brasileira, existe uma tendência de produzir sempre um discurso conservador, onde os valores morais tradicionais são defendidos pelos mais velhos $e$ pelos homens. Essa postura ainda se vê reproduzida não só pelos homens, mas também pelas mulheres que, ainda em grande quantidade, criam seus filhos e filhas reproduzindo esses valores tradicionais e conservadores.

DAMATTA $^{34}$ coloca ainda que a rua compensa a casa e a casa equilibra a rua. No Brasil, casa e rua são como os dois lados de uma mesma moeda. O que se perde de um lado, ganha-se do outro. O que é negado em casa - como o sexo e o trabalho - tem-se na rua. Novamente o motel entra como o espaço físico que

\footnotetext{
${ }^{31}$ SEGATO, Rita Laura. Os percursos do gênero na antropologia e ara além dela. Revista Sociedade e Estado. Dpto. De Sociologia da UNB. Feminino e gênero. Vol.XII, n.2, Brasília, Jul/dez, 1997.

${ }^{32}$ BANDEIRA, Lourdes \& SIQUEIRA, Deis. A perspectiva no pensamento moderno e contemporâneo. Revista Sociedade e Estado. Dpto. De Sociologia da UNB. Feminino e gênero.

Vol.XII, n.2, Brasília, jul-dez, 1997

${ }^{33}$ DAMATTA, Roberto. O que faz o Brasil Brasil? Rio de Janeiro: Rocco, 2000.

${ }^{34}$ Op.Cit. (2000:30)
} 
possibilita exercer esse outro lado, o da rua, como o local dos prazeres e da liberdade.

São muitos os espaços públicos em que se poderia exercer essa liberdade que a rua pressupõe, porém nenhum outro proporciona a privacidade e sigilo que os motéis nos moldes brasileiros, proporcionam. Os namoros nos carros como aconteciam nos das décadas de 50, 60 e 70, do século XX, já não são mais recomendados em função da violência urbana, assim como as praças e os cantinhos escurinhos espalhados pelas cidades. Os hotéis seriam uma opção, mas por serem ambientes abertos, também freqüentados pela população local, em função de seus bares, restaurantes e eventos, tornam-se lugares passíveis de se encontrar conhecidos. Assim os motéis por sua localização estratégica, fora dos centros das cidades, pelas características já citadas, proporcionando a providencial discrição e privacidade, têm se tornado o ambiente adequado para encontros reservados.

Encontros esses que não se dão somente nas relações extraconjugais, mas também por casais de namorados e os formalmente casados, uma vez que os motéis, em função de sua diversidade de ambiente, de sua decoração estimulante, do seu ar de mistério propício a fantasias, funcionam também como uma suspensão da rotina dos casais.

Esse tipo de empreendimento possibilita também algo difícil nos lares, que é a privacidade, ou seja, é a certeza de não ser interrompido por filhos, pais, parentes, telefonemas ou visitas. É um local propício à prática sexual, onde as fantasias podem ser realizadas sem a preocupação de ser surpreendido ou descoberto posteriormente.

Nesse sentido o motel ocupa um espaço oposto ao espaço do lar, da casa, caracterizada como familiar, sem privacidade e local de respeito onde o sexo é mais contido em função de familiares e vizinhos, como comprovou a pesquisa realizada com homens e mulheres adultos em Goiânia, e que será tratada a seguir. 


\title{
CAPÍTULO III
}

\section{REPRESENTAÇÃO SOCIAL DOS MOTÉIS: RESULTADOS DA PESQUISA DE CAMPO}

\author{
A representação social é um corpus \\ organizado de conhecimentos e uma das \\ atividades psíquicas graças às quais os \\ homens tornam inteligível a realidade física e \\ social, inserem-se num grupo ou numa \\ ligação cotidiana de trocas e liberam os \\ poderes de sua imaginação (MOSCOVICI, \\ 2002)
}

Como bem coloca Moscovici, as representações são construídas a partir de um conjunto de ações comuns a determinado grupo e são uma expressão de seus valores, crenças e sentimentos em relação aos elementos do mundo social a quê pertencem. No estudo aqui apresentado escolheu-se como objeto do mundo social o MOTEL, objetivando entender qual a representação social desse ambiente para homens e mulheres brasileiros.

Apesar das especificidades regionais do país, e conseqüentemente, as especificidades da capital goianas, neste estudo se estão centralizando a noção de povo brasileiro, tal como tratado por vários autores, como Ribeiro, já citado. Pensase que um estudo em qualquer cidade brasileira poderia indicar resultados semelhantes aos aqui obtidos, pois se tratam de representação sobre sexo, gênero, sexualidade, que informam a construção sócio-histórica-antropológica do povo brasileiro, não obstante suas especificidades regionais. 
O brasileiro, enquanto ser social influencia e é influenciado por um conjunto de objetivações vinculadas ao contexto histórico-social em que está inserido. Assim buscou-se entender como o homem e a mulher brasileiros vivenciam o ambiente do motel, qual o papel que esse tipo de empreendimento ocupa na sociedade em questão. Como ele é incorporados hoje no conjunto de costumes, valores, crenças, condutas cotidianas das pessoas, que são agentes sociais.

A sociedade brasileira atual vive momentos de distanciamento e aproximação da sociedade brasileira da década 50, do século XX. É uma sociedade que, em boa medida, pode ser pensada como dual que é moderna, sexualmente liberal em muitos aspectos; mas ainda assim reproduz valores características de uma sociedade conservadora e patriarcal. Nesse sentido, pode-se observar uma contraposição no significado do motel/profano e a da casa/sagrado, porém percebe-se uma ressignificação desse lugar profano, não como prejudicial, um mal para a sociedade, mas como uma opção de fuga do cotidiano, um lugar para se compensar as limitações impostas pelo caráter sagrado do lar, como local de respeito e de pouca privacidade.

\subsection{Caracterização dos Informantes}

O referencial da amostragem proposta para esse estudo parte do universo da Cidade de Goiânia, onde existem, hoje, 659.940 jovens e adultos na faixa dos 15 aos 59 anos, segundo dados do IBGE, Censo de 2000. Desse universo, foram pesquisados 80 mulheres e 74 homens na idade adulta, de 18 anos acima. Não se trata de uma amostra representativa, em termos estatísticos, o que seria muito difícil de ser realizado em uma monografia de final de curso de especialização. Mas o total de pessoas pesquisadas, ou seja, mais de 150, compõe um significativo número de informantes. Sobretudo se considerarmos a escassez de estudos que caracteriza a temática que está sendo investigada. Os resultados aqui apresentados têm, fundamentalmente, o caráter de subsídios para estudos e investigações posteriores. 


\subsection{Procedimentos da Pesquisa}

Optou-se aqui, por trabalhar com questionários quanti-qualitativos com perguntas fechadas e abertas, utilizando também a associação livre a partir de palavras geradoras.

A aplicação dos questionários se deu em ambientes com grande fluxo de pessoas/dia com idade, poder aquisitivo e estado civil diversificados, sendo estes sujeitos escolhidos aleatoriamente em shopping, supermercados e terminal de transporte urbano, constituindo-se uma amostra não probabilística. Entretanto, tratase de três espaços que representam, em boa medida, os vários estratos da sociedade.

Optou-se ainda por adotar a associação livre a partir das palavras geradoras: MOTEL e CASA, buscando-se identificar a relação dos significados desses dois ambientes a partir da associação de idéias com esses termos indutores e com isso apreender o significado ou a ressignificação desses para os brasileiros.

\subsection{Caracterização dos Sujeitos}

\subsubsection{Sujeito Masculino}

Gráfico 1:

Faixa Etária dos Entrevistados

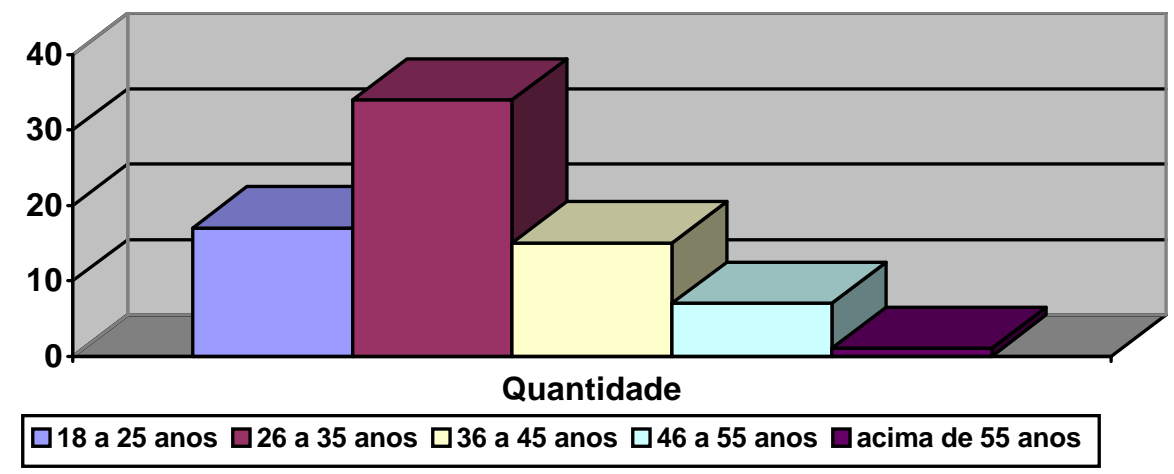

Fonte: pesquisa realizada pela autora no período de setembro e outubro/2003. 
A amostra escolhida aleatoriamente em shopping, supermercado, e terminal de transporte urbano, nos quais, como demonstra o gráfico 1, se dispuseram a responder o questionário, principalmente o público entre 26 a 35 anos, com 45,95 \%, seguidos dos homens mais jovens com 22,97\%, os homens de meia idade, correspondem a 20,27 \%; os homens de 46 a 55 anos correspondem a apenas 9,45 \%; e apenas um homem na faixa etária acima de 55 anos se predispôs a responder o questionário, correspondendo a 1,35 \%.

\section{Gráfico 2:}

Estado Civil

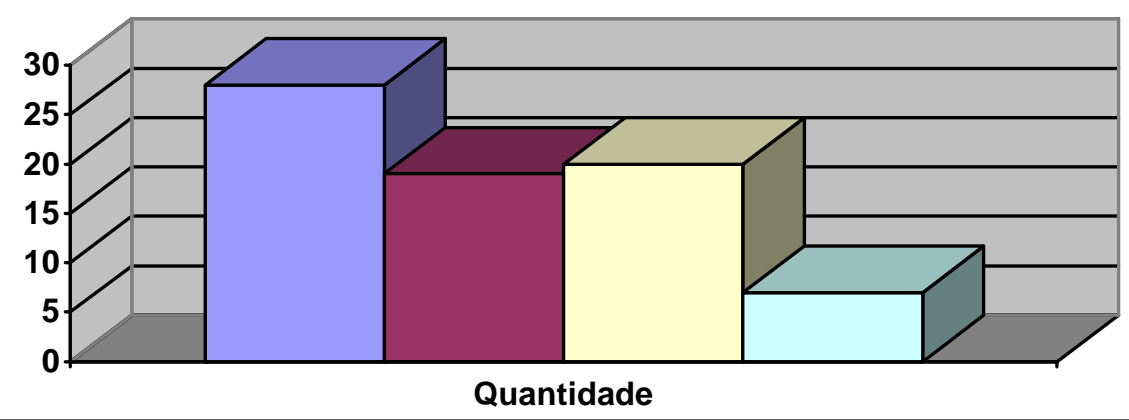

$\square$ solteiro com companheiro(a) fixo(a) $\square$ solteiro sem companheiro(a) fixo(a) $\square$ casado $\square$ viúvo

Fonte: pesquisa realizada pela autora no período de setembro e outubro/2003.

O gráfico 2 apresenta uma diferença que ultrapassa os 100\%, isso se dá um função de 03 (três) dos entrevistados que se declararam solteiros com companheira fixa, também assinalaram o item casados e justificaram se sentirem como se fossem formalmente casados com suas referidas companheiras. Ocorrência que não ocorreu nas entrevistas realizadas com o público feminino.

Ainda nesse gráfico, percebe-se uma incidência de homens solteiros com companheiro(a) fixo, com 37,83\%; seguido dos solteiros sem companheiro(a) fixo(a), com 25,67\%: já os casados, perfazem um percentual de 27,02 \%; e os viúvos de $9,45 \%$. 
Gráfico 3

Formação Educacional

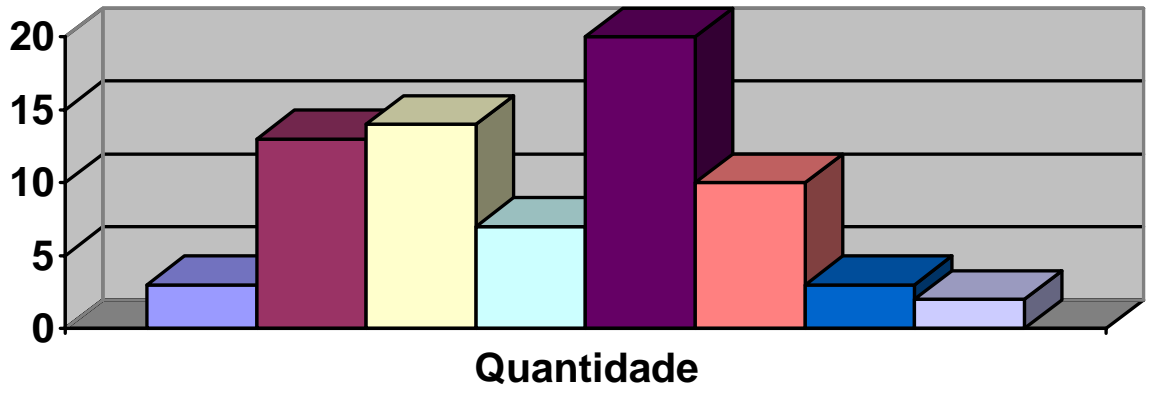

\begin{tabular}{|lll}
\hline pós graduação & $\square$ III grau completo & $\square$ III grau incompleto \\
$\square$ técnico & $\square$ ensino médio completo & $\square$ ensino médio incompleto \\
$\square$ ensino fundamental completo & $\square$ ensino fundamental incompleto
\end{tabular}

Fonte: pesquisa realizada pela autora no período de setembro e outubro/2003.

Com relação à formação educacional dos entrevistados o gráfico 3 nos mostra que, 27,02\% possuem ensino médio (II grau) completo; 18,91\% III grau incompleto; 16,21\% possuem III grau completo; 13,51\% possuem ensino médio (II grau) incompleto; 9,45\% possuem curso técnico; 4,05\% pós-graduação, bem como outros 4,05\% possuem ensino fundamental (I grau) completo; e, finalmente somente 2,7\% possuem apenas ensino fundamental (I graus) incompleto.

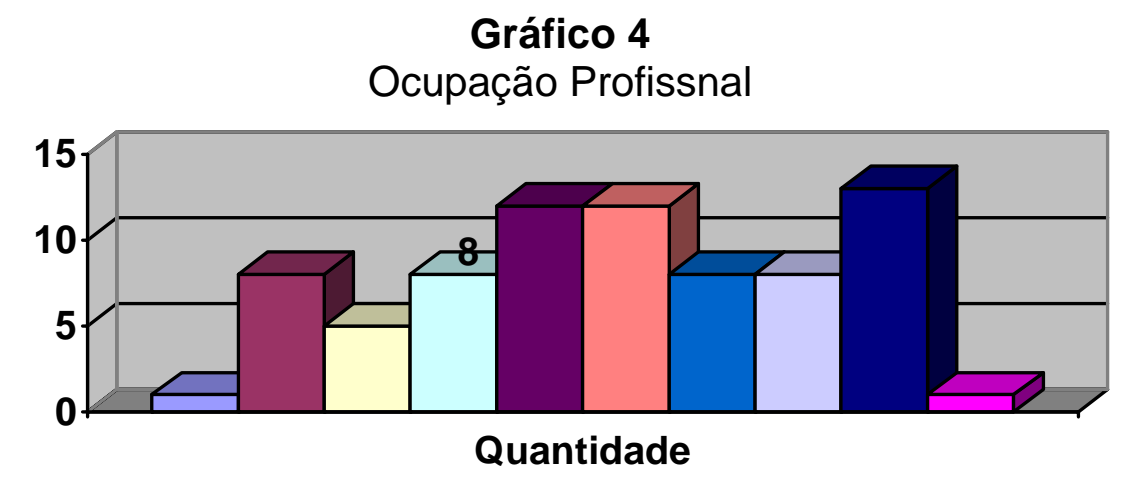

\begin{tabular}{|c|c|c|c|}
\hline$\square$ do lar & $\square$ estudante & 口empresário & $\square$ professor \\
\hline$\square$ comerciante & $\square$ atendente/loja & $\square$ funcionário público & $\square$ profissional liberal \\
\hline Doutros & $\square$ não respondeu & & \\
\hline
\end{tabular}

Fonte: pesquisa realizada pela autora no período de setembro e outubro/2003. 
Sobre a ocupação profissional dos sujeitos o gráfico 4 demonstra que, 17,56\% ocupam profissões diversas como auxiliar administrativo, padioleiro, e etc; 16,21\%são estudantes; $16,21 \%$ são atendentes/loja; que as ocupações de comerciantes. Professor, funcionário público e profissional liberal englobam, cada uma 10,81\% dos entrevistados; os empresários perfazem apenas 6,75\% dos sujeitos; 5,4\% não responderam; e, 5,4\% se declararam do lar, ocupação normalmente atribuída a mulheres, apontando aí um dos papéis intercambiáveis entre homem/mulher em mutação.

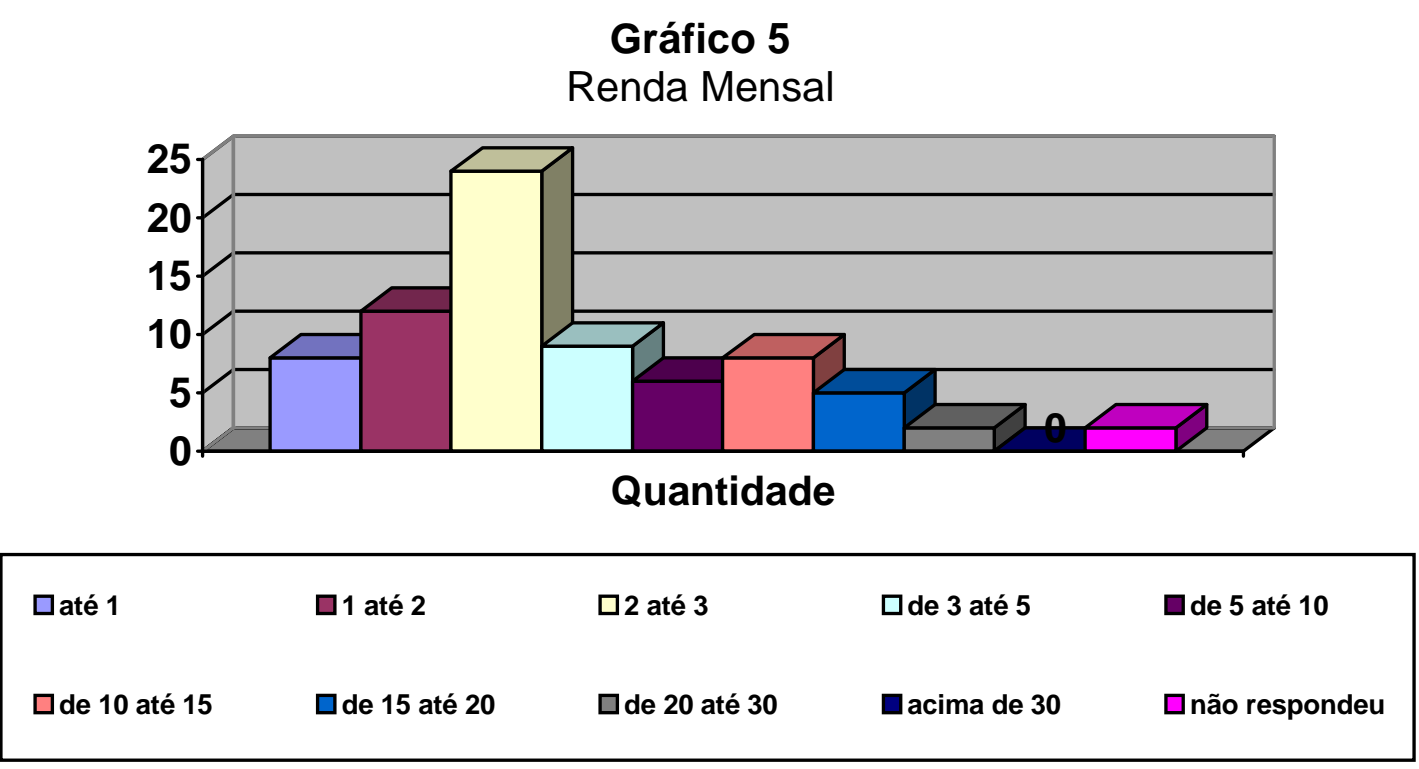

Fonte: pesquisa realizada pela autora no período de setembro e outubro/2003.

A renda mensal da maioria dos entrevistados varia entre 1 a 5 salários mínimos como se pode observar no gráfico 5, uma vez que se somar os percentuais que perfazem um total de $\mathrm{R} \$ 1.200,00$ mensais, o equivalente a 5 salários mínimos, ter-se-á um total de 66,21\% dos entrevistados; contra apenas 8,1\% percebendo entre 5 a 10 salários mínimos; 12,16\% com rendimentos mensais entre 10 e 15 salários mínimos; 6,75\% ganhando entre 15 e 20 salários mínimos; apenas 2,7\% recebendo entre 20 e 30 salários mínimos; e outros 2,7\% não quiseram responder quais suas rendas mensais. 


\subsubsection{Sujeito Feminino}

\section{Gráfico 6:}

Faixa Etária das Entrevistadas

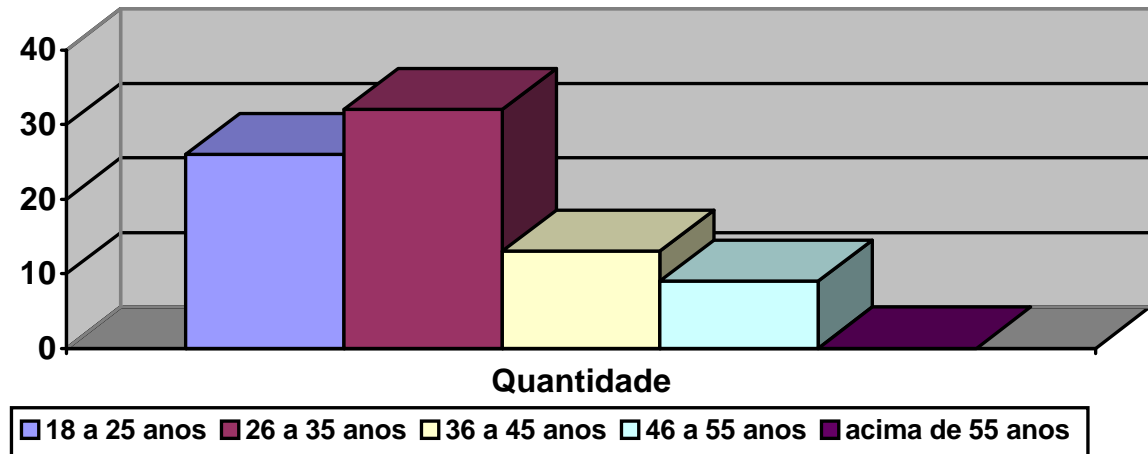

Fonte: pesquisa realizada pela autora no período de setembro e outubro/2003.

Em relação sujeito feminino percebe-se de acordo com o gráfico 6 que, entre as pessoas se dispuseram a responder o questionário, o público entre 26 a 35 anos, com $40 \%$, seguido das mulheres mais jovens com 32,5\%, já as mulheres de meia idade, correspondem a 16,25 \%; as mulheres de 46 a 55 anos correspondem a apenas 3,75 \%; e nenhuma mulher de terceira idade, acima de 55 anos, se predispôs a responder o questionário.

\section{Gráfico 7:}

\section{Estado Civil}

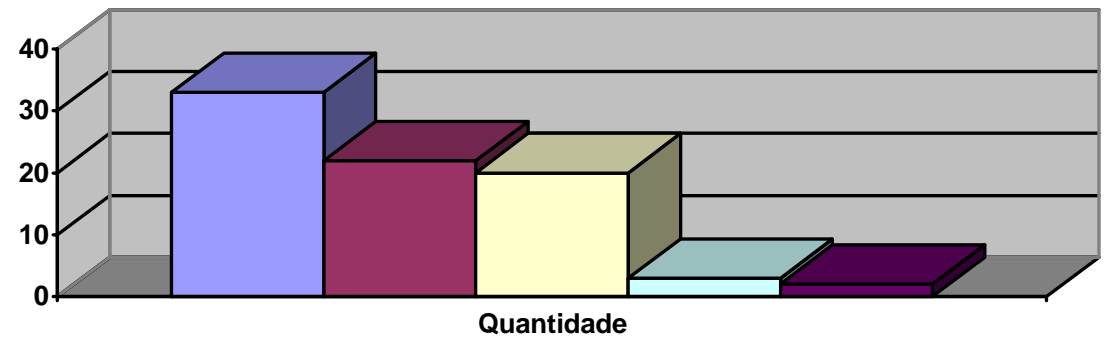
$\square$ solteiro com companheiro(a) fixo(a)
$\square$ casado
$\square$ solteiro sem companheiro(a) fixo(a)

$\square$ não responderam

Fonte: pesquisa realizada pela autora no período de setembro e outubro/2003.

Em relação ao estado civil apresentado pelos sujeitos femininos, o gráfico 7 demonstra que, 41,25\% são solteiras com companheiro(a) fixo; seguido das solteiras sem companheiro(a) fixo(a), com 27,5\%: já as casadas, perfazem um percentual de 25 \%; e as viúvas perfazem 3,75\% das entrevistas e 2,5\% não quiseram responder. 
Gráfico 8

Formação Educacional
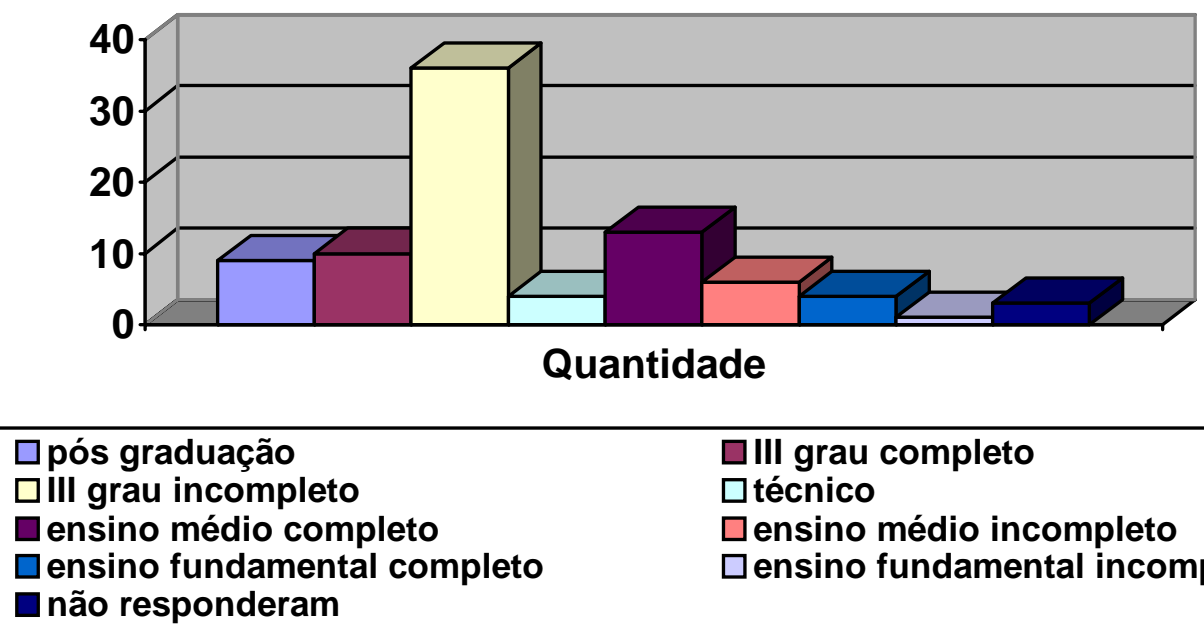

口III grau completo

$\square$ técnico

पensino médio incompleto

$\square$ ensino fundamental incompleto

Fonte: pesquisa realizada pela autora no período de setembro e outubro/2003.

Com relação à formação educacional das entrevistadas o gráfico 8 nos mostra que, 47,5\% III grau incompleto; 16,25\% possuem III grau completo; 12,5\% possuem ensino médio (II grau) completo; 11,25\% pós-graduação; 7,5\% possuem ensino médio incompleto; 5\% possuem curso técnico: outros 5\% ensino fundamental (I grau) completo; 1,25\% possui apenas ensino fundamental (I grau) incompleto; e, 2,5\%não responderam.

\section{Gráfico 9}

Ocupação Profissional

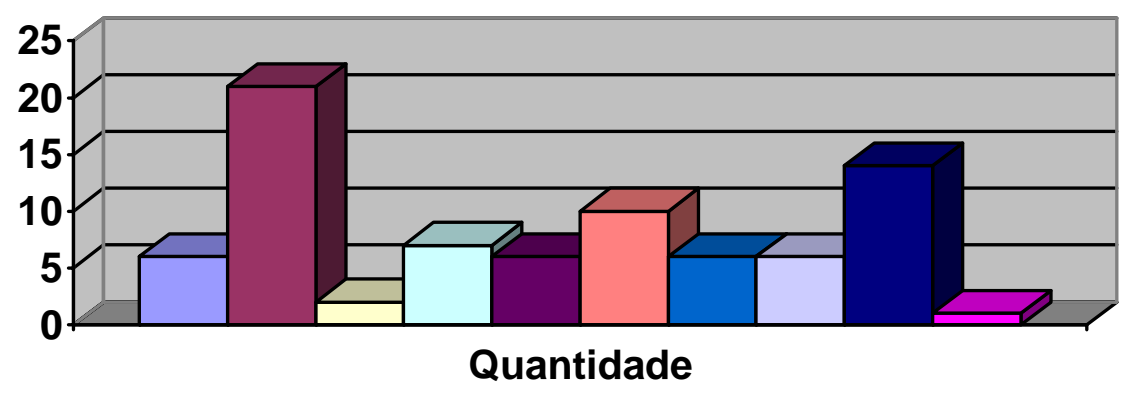

\begin{tabular}{|llll|}
\hline$\square$ do lar & $\square$ estudante & $\square$ empresário & $\square$ professor \\
$\square$ comerciante & $\square$ atendente/loja & $\square$ funcionário público & $\square$ profissional liberal \\
$\square$ outros & $\square$ não respondeu & & \\
\hline
\end{tabular}

Fonte: pesquisa realizada pela autora no período de setembro e outubro/2003.

Sobre a ocupação profissional dos sujeitos femininos o gráfico 9 demonstra que, 28,75\% são estudantes; $17,5 \%$ ocupam funções diversas, tais como enfermeira, esteticista, auxiliares administrativos, e etc; $12,5 \%$ são atendentes/loja; 8,75\% são 
professoras; e as ocupações de comerciante, funcionário público e profissional liberal e do lar englobam, cada uma 7,5\% das ocupações das entrevistadas; os empresários perfazem apenas 2,5\% dos sujeitos femininos; e, 1,25\% não respondeu.

\section{Gráfico 10}

Renda Salarial
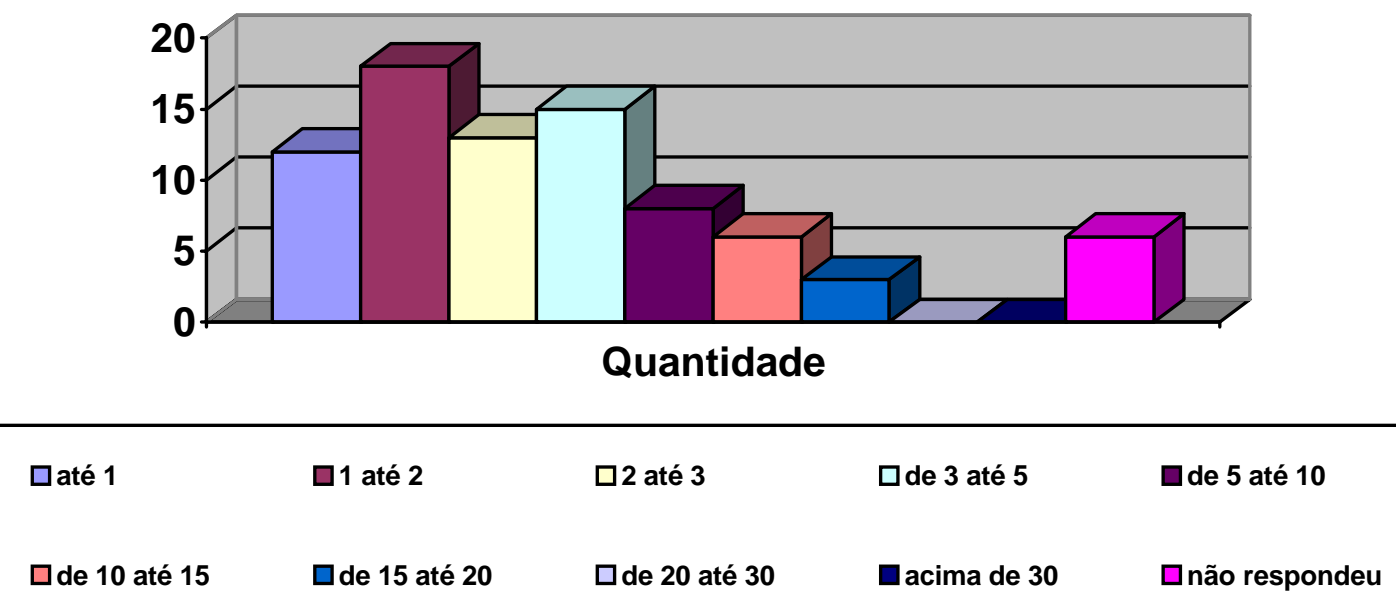

Fonte: pesquisa realizada pela autora no período de setembro e outubro/2003.

A renda salarial da maioria das entrevistadas situa-se entre 1 a 5 salários mínimos se pode observar no gráfico 10, uma vez que se somar os percentuais que perfazem um total de R $\$ 1.200,00$ mensais, o equivalente a 5 salários mínimos, terse-á um total de 72,5\% dos entrevistados; contra apenas 10\% percebendo entre 5 a 10 salários mínimos; 7,5\% com rendimentos mensais entre 10 e 15 salários mínimos; 3,75\% ganhando entre 15 e 20 salários mínimos; nenhuma das entrevistadas recebe acima de 20 salários mínimos; e outras 7,5\% não quiseram responder quais suas renda salarial. Essa realidade percebida reforça a idéia de que as mulheres ainda continuam ganhando menos que os homens no mercado de trabalho. 


\subsubsection{Análise Comparativa dos Sujeitos}

Fazendo uma análise comparativa entre os sujeitos pesquisados pode-se perceber que as variáveis mais significantes estão relacionadas ao alto número de pessoas com companheiros(as) fixos(as) tanto entre os sujeitos masculinos, quanto entre os sujeitos femininos, estejam eles em situação de coabitação de lares ou namoros firmes com moradias separadas. Levando-se em consideração que as relações sexuais são comuns desde as fases iniciais dos namoros de hoje em dia, pode-se inferir que esse seria, em princípio, um dos principais públicos usuários dos motéis no Brasil.

A liberdade sexual característica nos dias atuais torna, a parcela da população que se apresenta sem parceiro(a) fixo(a), um percentual da população que também é um forte potencial de usuários de motéis, uma vez que a rotatividade de parceiros é muito alta com a prática do 'ficar' 35 , muito comum entre os adultos, principalmente os adultos jovens.

Os casados também são usuários em potencial, porém a casa é o principal local para a prática sexual.

Já em relação, a formação educacional percebe-se que as mulheres possuem maior formação educacional que os homens, apresentando 47,5\% cursando o III grau, 16,25\% já formadas e 11,25\% com pós-graduação; enquanto os homens apresentam percentuais bem menores, 18,91\% cursando III grau, 16,21\% já formados e 4,05\% com pós-graduação. Dado que parece confirmar uma presença expressiva das mulheres nas escolas e faculdades do país.

Porém, essa supremacia feminina percebida na formação educacional não garante o mesmo nível de empregos e muito menos rendimentos salariais compatíveis aos dos homens, mais uma das contradições desse início de século XXI. Os resultados demonstraram uma presença menor da mulher em termos de ocupação profissional. Já em relação aos salários 72,5\% das mulheres, contra 66,21\% dos homens ganham até 5 salários mínimos; enquanto que 21,62\% dos homens contra 11,25\% das mulheres percebem rendimentos acima de 10 salários mínimos,

\footnotetext{
${ }^{36}$ Entende-se por ficar, o ato de sair para festas, bares e etc, encontrar ou conhecer uma pessoa que não se tem um relacionamento fixo e namorar incluindo, freqüentemente, a relação sexual, por aquele dia.
} 
confirmando os dados mais gerais para o país de que as mulheres, com a mesma formação e ocupando os mesmos cargos, ganham menos do que os homens.

\subsection{Hábitos dos Sujeitos em Relação aos Motéis}

\subsubsection{Hábitos Masculinos}

Gráfico 11

Tem o Hábito de Freqüentar Motéis

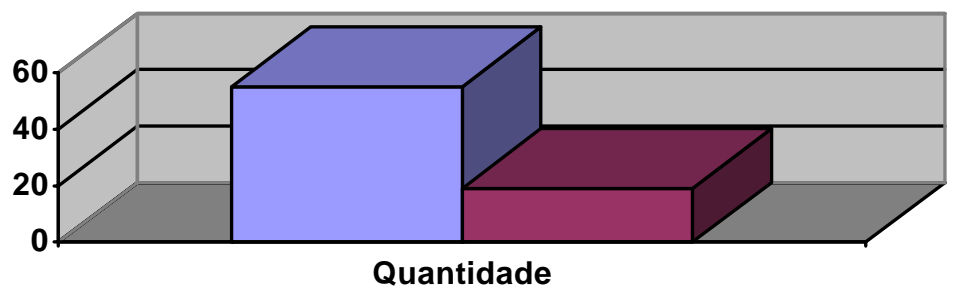

口sim anão

Fonte: pesquisa realizada pela autora no período de setembro e outubro/2003.

Entre os homens pesquisados, 74,32\% declaram ter hábito de freqüentar motéis e apenas 25,61\% não possuem o hábito de freqüentar motéis. Ou seja, cerca de 2/3 dos informantes opinaram sobre os motéis com conhecimento de causa.

Gráfico 12

Com que Freqüência vai ao Motel?

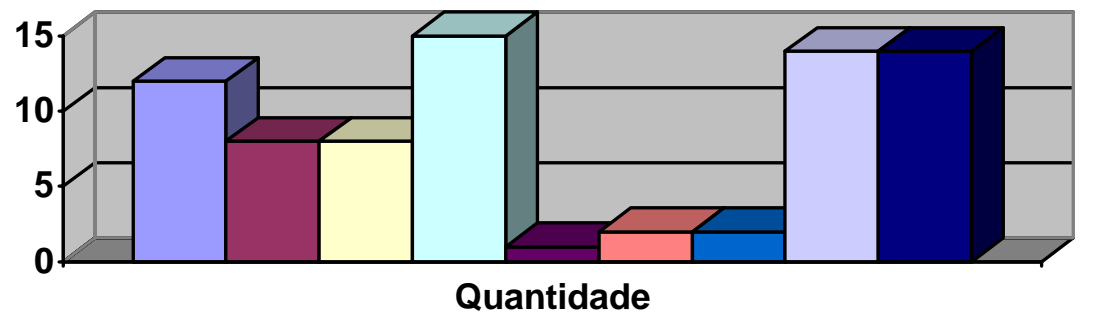

$\square 01$ vez por semana

$\square$ nos finais de semana

$\square 03$ vezes por mês

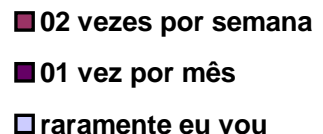

$\square$ raramente eu vou $\square 03$ vezes por semana $\square 02$ vezes por mês não respondeu

Fonte: pesquisa realizada pela autora no período de setembro e outubro/2003. 
Em relação à freqüência que costuma ir a motéis o público masculino declarou que, como demonstra o gráfico 12, 20,27\% freqüentam os motéis nos finais de semana; 18, 91\% raramente vão a motéis; 16,21\% freqüentam 01 vez por semana; 10,81\% vão 02 vezes por semana; outros 10,81\% vão 03 vezes por semana; 5,4\% vão apenas 01 vez por mês; 2,7\% vão 02 vezes ao mês; outros 2,7\% costumam ir 03 vezes ao mês nos motéis; e, 18,91\% não responderam.

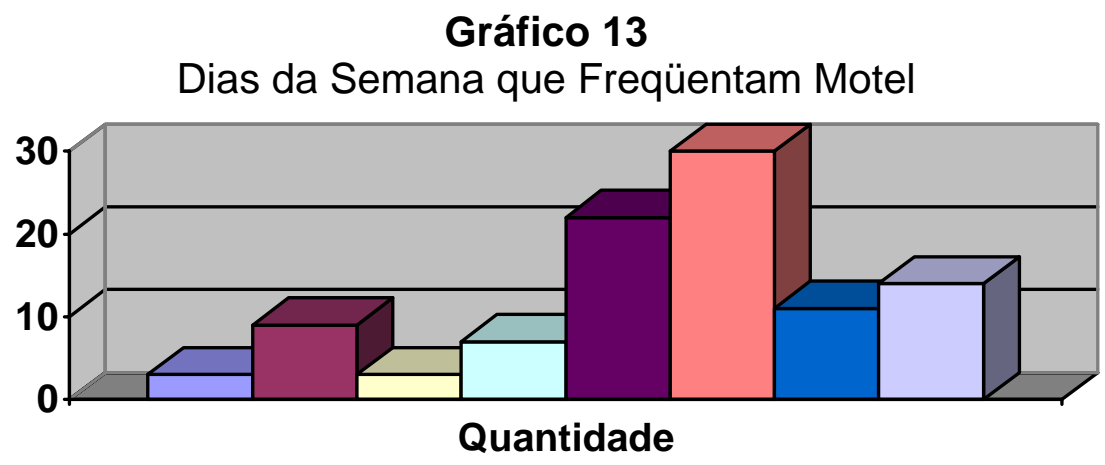

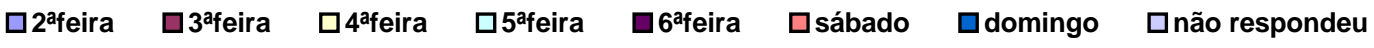

Fonte: pesquisa realizada pela autora no período de setembro e outubro/2003.

Em relação ao dia da semana que costuma ir a motéis, o gráfico 13 demonstra que, 40,54\% dos sujeitos masculinos preferem o sábado; seguido de 29,72\% que vão às 6. feiras; $14,86 \%$ costumam ir aos domingos; já $10,81 \%$ preferem às 3 . feiras; $9,45 \%$ freqüentam os motéis as 5 . feiras; 4,05\% às 4 . feiras; outras 4,05\% preferem às 2. feiras; e 18,91\% não responderam.

Gráfico 14

Horário que Costuma Ir ao Motel I

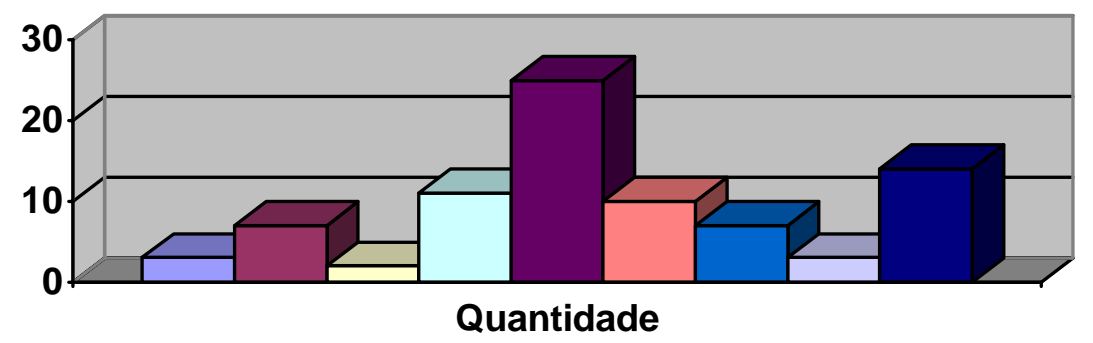

$\square$ entre 07:00 e 11:00 $\square$ entre 11:00 e 14:00 $\square$ entre 14:00 e 17:00 $\square$ entre 17:00 e 21:00 $\square$ entre 21:00 e 00:00

$\square$ entre 00:00 e 03:00 $\square$ entre 03:00 e 07:00 $\square$ outro (pernoite )

घão respondeu

Fonte: pesquisa realizada pela autora no período de setembro e outubro/2003. 
Com relação ao horário em que costuma ir aos motéis o público masculino apontou que, 33,78\% costumam ir entre 21:00 e 00:00; 14,86\% preferem o horário compreendido entre 17:00 e 21:00; 13,51\% preferem o horário, de 00:00 às 03:00; 9,45\% freqüentam entre 11:00 e 14:00; e outros 9,45\% já preferem o horário entre 03:00 e 07:00 da manhã; 4,05\% preferem o horário das 07:00 às 11:00; também 4,05\% já preferem pernoitar nos motéis; 2,7\% freqüentam entre 14:00 e 17:00, 18,91\% não opinaram a respeito. Ou seja, a grande preferência se dá pela noite e não durante o dia.

\subsubsection{Hábitos Femininos}

Gráfico 15

Tem o Hábito de Freqüentar Motéis

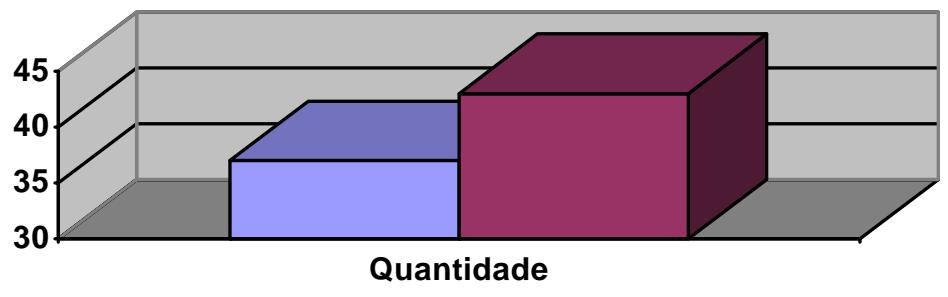

$\square \operatorname{sim} \quad$ não

Fonte: pesquisa realizada pela autora no período de setembro e outubro/2003.

Entre as mulheres pesquisadas, 53,75\% declaram não ter hábito de freqüentar motéis contra 46,25\% que possuem o hábito de freqüentar motéis. O público feminino entrevistado freqüenta bem menos os motéis que o público masculino. Para muitas mulheres freqüentar motéis ainda é tabu, até mesmo porque não é raro se escutar mulheres dizendo que gostariam muito de conhecer um motel, mas que o marido não leva ou algo do gênero. 
Gráfico 16

Com que Freqüência vai ao Motel?

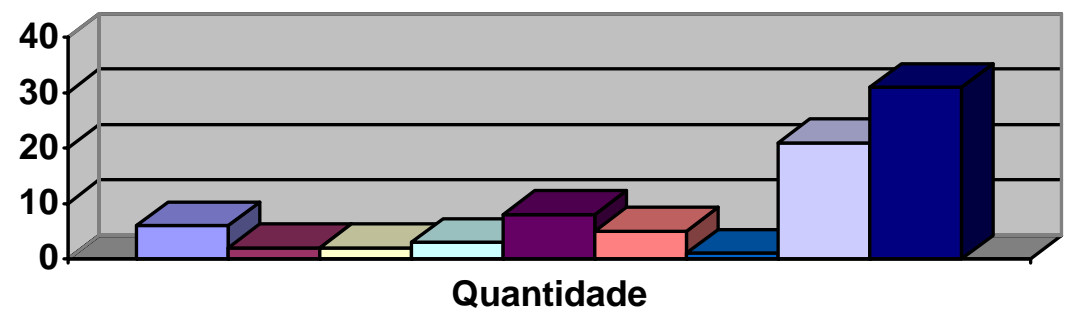

$\square 01$ vez por semana

$\square$ nos finais de semana

$\square 03$ vezes por mês $\square 02$ vezes por semana

$\square 01$ vez por mês

$\square$ raramente eu vou $\square 03$ vezes por semana

$\square 02$ vezes por mês

$\square$ não respondeu

Fonte: pesquisa realizada pela autora no período de setembro e outubro/2003.

Em relação à freqüência que costuma ir a motéis o público feminino declarou que, como demonstra o gráfico 16, 26,25\% raramente vão a motéis; $10 \%$ freqüentam motéis 01 vez ao mês; 7,5\% freqüentam 01 vez por semana; 6,75\% vão 02 vezes por mês; $5 \%$ vão a motéis 03 vezes por mês; 3,75\% vão somente nos finais de semana; e $2,5 \%$ vão 02 vezes por semana; outros $2,5 \%$ costumam ir 03 vezes por semana a motéis; e 38,75\% não responderam. É perceptível que a mulher freqüenta bem menos os motéis que os homens, porém a maioria dos casais que freqüentam os motéis é heterossexual. Diante dessa contradição pode-se supor que os homens apresentam uma rotatividade muito maior de parceiros que as mulheres.

Gráfico 17

Dias da Semana que Freqüentam Motel

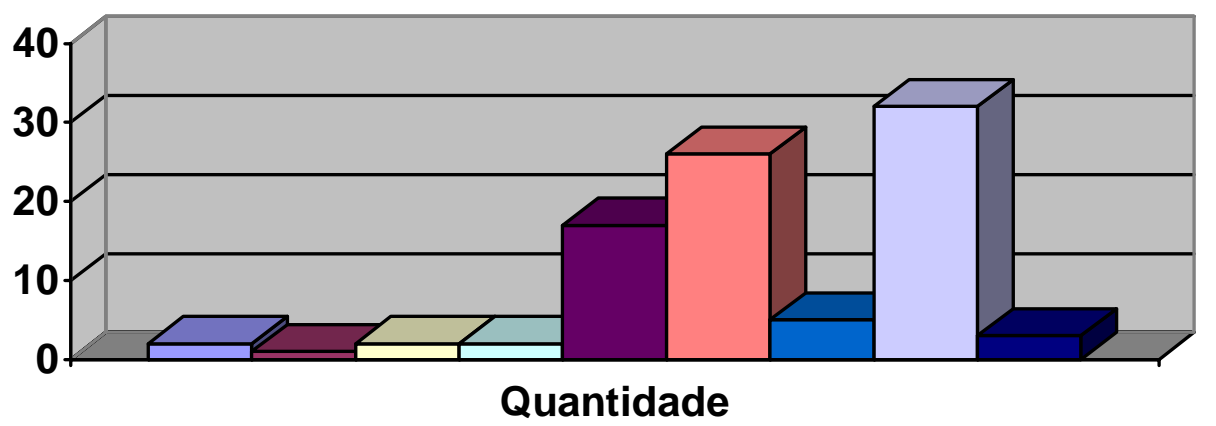

$\square 2^{\text {affeira }} \square 3^{\text {afeira }} \square 4^{\text {affeira }} \square 5^{\text {affeira }} \square 6^{\text {afeira }} \square$ sábado $\square$ domingo $\square$ não respondeu $\square$ qualquer dia

Fonte: pesquisa realizada pela autora no período de setembro e outubro/2003. 
Em relação ao dia da semana que costuma ir a motéis, o gráfico 13 demonstra que, 32,5\% dos sujeitos femininos freqüentam os motéis aos sábados; seguido de $21,25 \%$ que vão às 6 . feiras; os domingos são freqüentados por 6,75\% das mulheres; e as 2. feiras, 4 . feiras e 5 . feiras são freqüentadas por apenas $2,5 \%$ respectivamente, das mulheres entrevistas; somente 1,25\% preferem às 3 . feiras; $2,5 \%$ declaram que vão a qualquer dia, não tendo dia específico; e a grande maioria, 40\% não responderam.

Levando-se em consideração que a maioria das mulheres que freqüentam motel tem companheiro fixo, pode-se inferir que tal situação aponta para a hipótese de que ir aos motéis é um programa de fim de semana, como se fosse um lazer extra, provavelmente com seus parceiros fixos, enquanto para os homens, que apresentam grande freqüência durante a semana, que provavelmente seja nesses dias que aconteça a maior rotatividade de parceiras e/ou parceiros.

\section{Gráfico 18}

Horário que Costuma Ir ao Motel

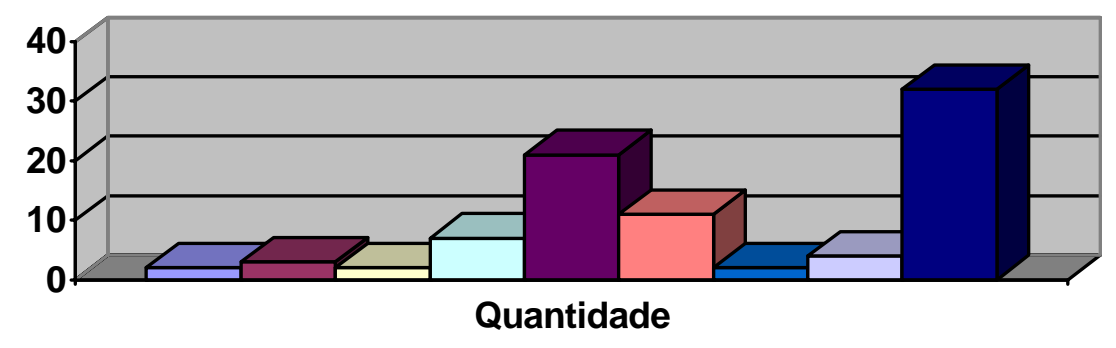

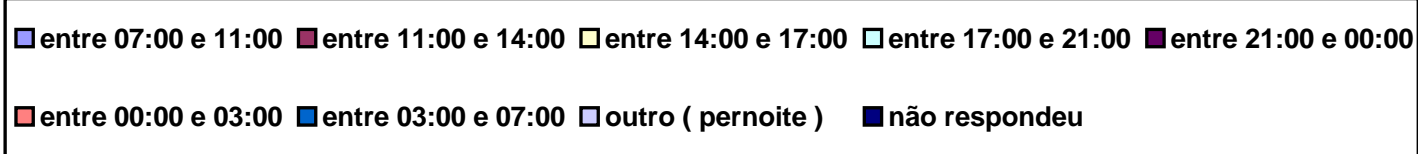

Fonte: pesquisa realizada pela autora no período de setembro e outubro/2003.

Com relação o horário em que costuma ir aos motéis o público feminino apontou que, 26,25\% costumam ir entre 21:00 e 00:00; 13,75\% preferem o horário compreendido entre 00:00 e 03:00; 8,75\% preferem o horário, de 17:00 às 21:00; 5\% freqüentam pernoitar no motel; 2,5\% respectivamente preferem os horários compreendidos entre 07:00 e 11:00 da manhã, 11:00 e 14:00 horas, 14:00 às 17:00 e 03:00 e 07:00 horas; e, 40\% não opinaram a respeito. Os horários apresentados como 
preferências pelas entrevistas são horários considerados, em termos probabilísticos, em que se está com companheiro fixo, o mesmo para os homens, ou seja, menos propícios a traições.

\subsubsection{Análise Comparativa dos Hábitos Referente aos Motéis dos Sujeitos}

Sobre os hábitos em relação ao motel há uma grande discrepância entre o comportamento masculino e feminino, sendo um grande percentual de sujeitos masculinos (74,32\%) que tem o hábito de freqüentar motéis, contra apenas 46,25\% e em relação ao percentual que não freqüentam o público masculino compreende somente $25,61 \%$ e mais que o dobro disso $(53,75 \%)$ do público feminino não freqüentam motéis. Essa realidade aponta a tendência de que os homens têm maior número de relações sexuais do que as mulheres, bem como possivelmente que essa freqüência maior também pode significar um maior número de parceiras. Para se ter maior certeza a respeito dessa questão será necessário aprofundar a pesquisa em relação aos hábitos sexuais, o que não é objeto principal desse estudo.

O fato de não terem o hábito de freqüentar motéis não quer dizer que não tenham ido anteriormente ou que ainda vão uma vez ou outra, em função disso alguns dos entrevistados, tanto homens como mulheres, mesmo tendo declarado não freqüentarem habitualmente, responderam as questões relativas há dias, horários e etc.

Em relação a quantidades de vezes ao longo da semana ou mês comparandose os hábitos masculinos e femininos percebe-se que a grande maioria dos homens (58,1\%) freqüenta os motéis semanalmente, contra uma minoria das mulheres que freqüentam motéis semanalmente (1625\%). Quando se amplia o espaço de tempo a situação se inverte, apesar de apresentar percentuais menores, ou seja, somente 10,8\% dos homens freqüentam motéis de uma a três vezes por mês, enquanto dobra o percentual de mulheres que freqüentam os motéis de uma a três vezes por mês (21,75\%). Em relação aos entrevistados que raramente vão a motéis as mulheres também são maioria, com 26,25\% contra uma minoria de 18,91\% dos homens. 
Apesar de a maioria dos usuários de motéis se constituírem de casais heterossexuais, os resultados da pesquisa apontam por uma freqüência bem maior dos homens nesses ambientes, isso reforça ainda mais a idéia - senso comum - de que o espaço da rua ainda é mais masculino que feminino, reforça também a idéia de que o homem tem uma rotatividade de parceiras(os) bem maior que a mulher, e reforça ainda, que o homem tende a ser mais infiel que a mulher.

Entre os sujeitos entrevistados os homens são os principais freqüentadores dos motéis nos dias de semana, 2 a 5 . feira, com 28,36\% e apenas uma pequena minoria das mulheres entrevistadas freqüentam os motéis nesses dias da semana, com 8,76\%. A 6. feira e o sábado são os campeões de procura por ambos os sujeitos entrevistados, porém os homens perfazem 70,26\% , contra 53,75\% do público feminino. O domingo apresenta uma freqüência bem menor, mas ainda assim os homens são maioria (14,86\%), contra 6,75\% de mulheres.

Em relação ao horário não se percebe grandes discrepâncias, sendo que os percentuais acompanham a quantidade de pessoas que freqüentam os motéis.

\subsection{Representação Social dos Motéis para os Sujeitos}

\subsubsection{Representação Social para o Sujeito Masculino}

\section{Gráfico 19}

O Que Chama a Atenção no Motel

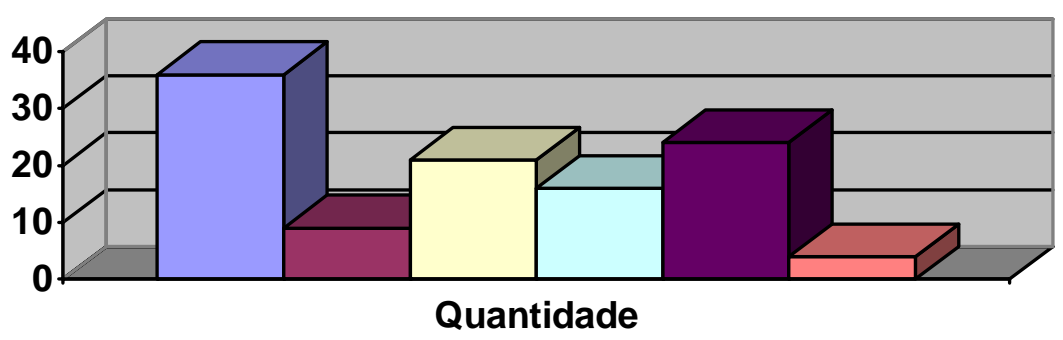

\begin{tabular}{|ll|}
\hline$\square$ privacidade & $\square$ decoração \\
$\square$ mudança de ambiente & $\square$ mistério16 \\
$\square$ variedade de ambientes oferecidos & $\square$ outros \\
\hline
\end{tabular}

Fonte: pesquisa realizada pela autora no período de setembro e outubro/2003. 
Questionados sobre o que mais chama a atenção no Motel, 48,64\% do público masculino apontam a privacidade como o principal elemento; seguido pela variedade de ambientes oferecidos com 32,43\%; já a mudança de ambiente também chama a atenção de 28,37\%; o ar de mistério desperta a atenção de 21,62\% dos entrevistados; 12,16\% apontaram a decoração como elemento que chama atenção nesse tipo de empreendimento; seguido de 5,4\% de homens que apontaram outros motivos. Ou seja, o motel é um ambiente que permite a privacidade seja com os parceiros fixos ou não, e isso tende a reforçar a idéia corrente de ser um local de traição.

\section{Gráfico 20}

Qual o Significado do Motel

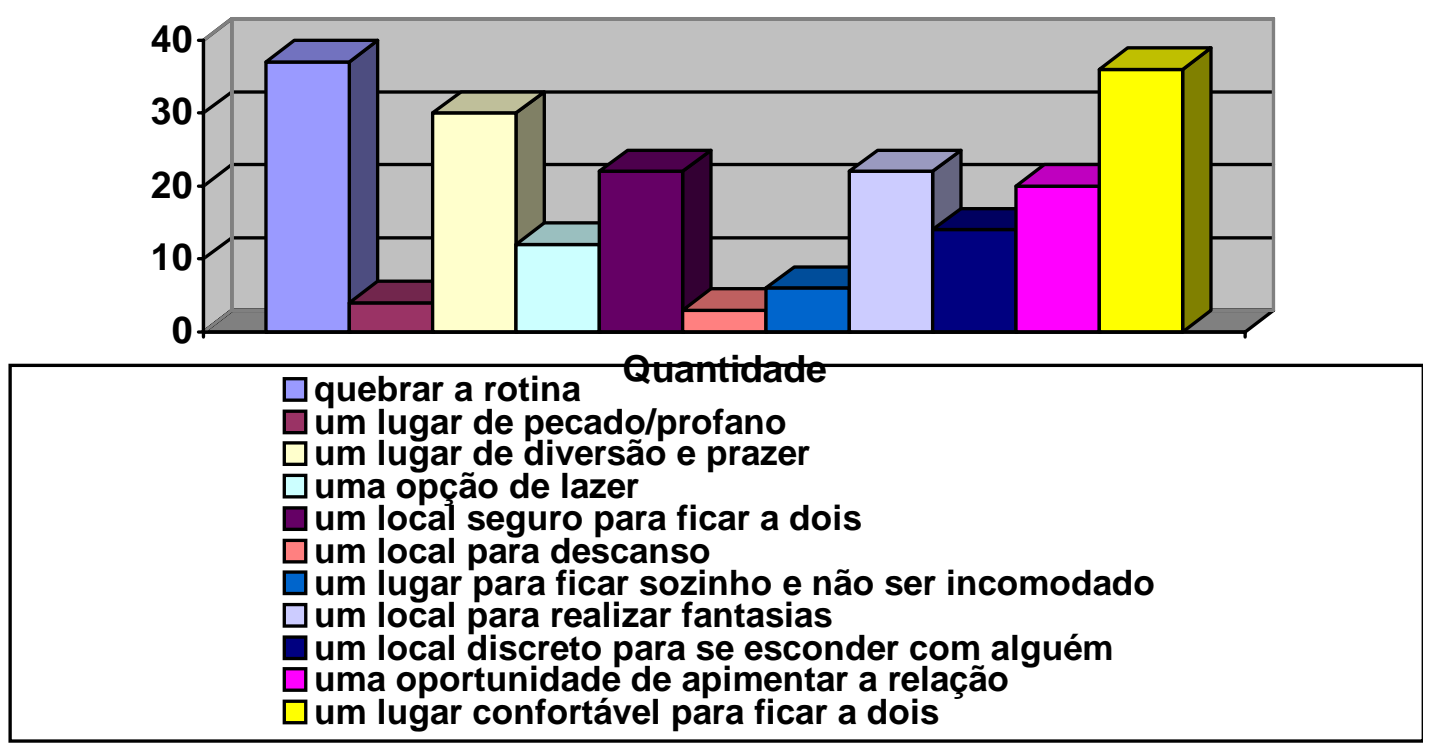

Fonte: pesquisa realizada pela autora no período de setembro e outubro/2003.

Em relação ao significado dos motéis, a somatória dos percentuais ultrapassa os $100 \%$ por ser uma questão de múltipla escolha, ou seja, o motel pode ter mais de um significado para uma mesma pessoal.

Para 50\% do sujeito masculino os motéis representam uma quebra de rotina; seguido de 48,64\% que vêem os motéis como um lugar confortável para ficar a dois; 40,54\% os motéis como local de diversão e prazer; para 32,43\% dos entrevistados os motéis significa um local seguro para se ficar a dois; e outros 32,43\% apontaram como o motel como um local próprio para se realizar fantasias sexuais; 27,02\% vêem 
no motel uma oportunidade de apimentar a relação; seguido de 18,91\% que encontram no motel um local discreto para se esconder com alguém; 16,21\% vêem um motel como uma opção de lazer; para 8,1\% dos entrevistados é um local para ficar sozinho e não ser incomodado; para 5,4\% o motel tem significado negativo, ou seja, representa um local de pecado/profano; 4,05\% acham que o motel é também um local para descanso; e 2,7 vê os motéis como um local de descanso.

\section{Gráfico 21}

Se você tem ou tivesse filho(a) jovem permitira que:

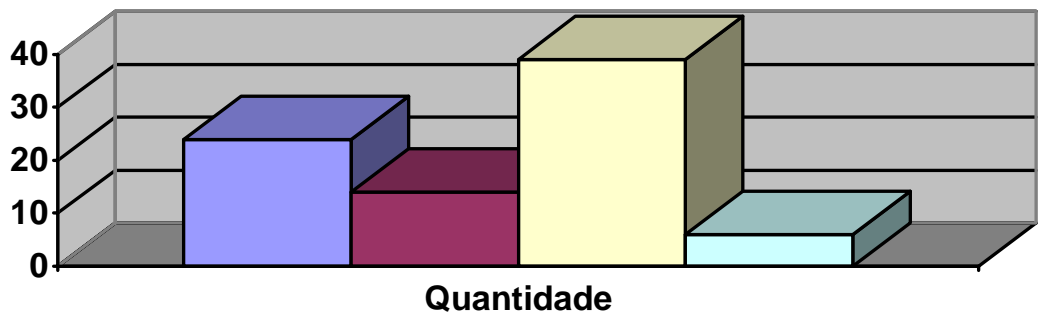

$\square$ Seu filho trouxesse a namorada para dormirem juntos na sua casa

$\square$ Sua filha trouxesse a namorada para dormirem juntos na sua casa

$\square$ Não permitira que nem filho e nem filha trouxessem namorado(a) para dormirem juntos na sua casa

$\square$ não responderam

Fonte: pesquisa realizada pela autora no período de setembro e outubro/2003.

Quando questionados sobre a aceitação de que os filhos(as) levem seus namorados(as) para dormirem em suas casas, o gráfico 21 demonstra que, 52,7\% dos entrevistados não permitiram que seus filhos(as) levassem namorados(as) para dormirem em casa; 32,42\% permitiram que apenas os filhos (homens) levassem namoradas para dormirem juntos em casa; e praticamente a metade 18, 91\% permitiria que suas filhas (mulher) levem seus namorados para dormirem em casa; e $8,1 \%$ dos entrevistados não responderam.

Levando-se em consideração que a mais 70\% desses mesmos entrevistados freqüentam motéis e boa parte desses freqüentam semanalmente os motéis, percebese ai, um comportamento bastante conservador e machista, bem parecido ao comportamento no período do Brasil-Colônia, ou dos anos dourados, em casa um comportamento contido e na rua bastante libertino. 


\section{- Questões Abertas}

A utilização da técnica de associação livre de palavras e idéias visou auxiliar na redução do nível de interferência das racionalizações discursivas, permitindo assim, perceber mais facilmente, os elementos organizadores da representação dos motéis para os entrevistados. Foram utilizadas como palavras indutoras: motel e casa, nas quais buscou-se identificar as representações sociais desses ambientes e contrapondo-se o espaço do lar com o espaço do motel.

\section{a) Quando pensa na palavra MOTEL, qual a primeira coisa que vem a sua cabeça? :}

As associações de idéias feitas em relação aos motéis, para efeito de análise estão classificadas em 5 grupos que aglutinam associações de acordo com as categorias identificadas a partir das idéias apresentadas. São elas: ambiente físico: idéias que se relacionam com estrutura física dos motéis; sexualidade: aglutinam idéias que fazem alusão à sexualidade; caráter reservado, nessa categoria está associado às idéias ligadas à privacidade; Aspectos negativos concentram as associações com coisas negativas a respeito do ambiente de motel; e por último Suspensão do Cotidiano, com associação ligada a fuga da rotina. Essas categorias não são fechadas e estanques, pelo contrário, são intercambiáveis e muitas vezes uma idéia perpassa outras categorias.

\begin{tabular}{|c|c|}
\hline SEXUALIDADE & $\begin{array}{l}\text { Sexo (27 ocorrências); } \\
\text { Prazer (12 ocorrências); } \\
\text { Fantasia (07 ocorrências); } \\
\text { Diversão/Lazer ( } 06 \text { ocorrências); } \\
\text { Amor (04 ocorrências); } \\
\text { Vadiação e sacanagem; } \\
\text { Ficar a dois; } \\
\text { Amar de forma mais louca que possa imaginar; } \\
\text { Erotismo; } \\
\text { Onde não há nada de ruim, só tesão e sexo; }\end{array}$ \\
\hline $\begin{array}{l}\text { CARÁTER } \\
\text { RESERVADO }\end{array}$ & $\begin{array}{l}\text { Privacidade (04 ocorrências); } \\
\text { Tranqüilidade (02 ocorrências); } \\
\text { Intimidade (02 ocorrências); } \\
\text { Não ser incomodado; } \\
\text { Sair para a festa conquistar alguém e depois ficar com ela num } \\
\text { ambiente reservado; }\end{array}$ \\
\hline
\end{tabular}




\begin{tabular}{|l|l|}
\hline $\begin{array}{l}\text { SUSPENSÃO } \\
\text { DO } \\
\text { COTIDIANO }\end{array}$ & $\begin{array}{l}\text { Quebra de Rotina (03 ocorrências); } \\
\text { Diferente; } \\
\text { Presente para minha esposa; } \\
\text { Aproveitar o tempo livre; }\end{array}$ \\
\hline AMBIENTE & Conforto; \\
FÍSICO & $\begin{array}{l}\text { Comodidade; } \\
\text { Quarto confortável e lugar romântico; } \\
\text { Lugar seguro, decorado com estilo romântico que desperta o } \\
\text { sentimento de amor e romantismo aonde duas pessoas podem } \\
\text { realizar suas fantasias e prazeres em uma relação amorosa; }\end{array}$ \\
\hline ASPECTOS & $\begin{array}{l}\text { Imoralidade; } \\
\text { NEGATIVOS }\end{array}$ \\
& $\begin{array}{l}\text { Sujo; } \\
\text { Nada; } \\
\text { Proibido }\end{array}$ \\
\hline
\end{tabular}

\section{b) Fazendo uma comparação entre o motel e a sua casa como classificaria cada um deles?}

Na comparação livre entre os ambientes da casa e do motel pode-se manter as mesmas categorias (sexualidade, caráter reservado, suspensão do cotidiano, ambiente físico e aspectos negativos) utilizadas na associação anterior, porém para a associação com a palavra casa às semelhanças e proximidades semânticas levou a definição de novas categorias, são elas: sagrado/familiar: associações que levam a idéia de um local particular, puro, de respeito, convívio, comunhão e segurança; cotidianidade: idéias pertinentes à mesmice do dia-a-dia; falta de privacidade idéias que relacionam a casa como um lugar de convivência e liberdade, mas o 'eu’ sempre dá lugar ao 'nós’; outros, associações diversas.

\section{MOTEL}




\begin{tabular}{|l|l|}
\hline SEXUALIDADE & Sexo (10 ocorrências); \\
& Prazer (07 ocorrências); \\
& Fantasias (03 ocorrências); \\
& Saciar desejos; \\
& Afrodisíaco; \\
& Emoção; \\
& Loucura; \\
& Sacanagem; \\
& O motel representa o lugar diferente, especial para amar sem \\
& rotina e sim, muita harmonia no ambiente que está relacionado \\
& com o momento; \\
\hline CARÁTER & Privacidade (07 ocorrências); \\
RESERVADO & Discreto (02 ocorrências); \\
& Ficar a dois (02 ocorrências); \\
Esconder; & Mais privativo, em que se tem a certeza de que não chegará \\
ninguém.
\end{tabular}

\begin{tabular}{|l|l|}
\hline \multicolumn{2}{|c|}{ CASA } \\
\hline SAGRADO / & Familiar (18 ocorrências); \\
FAMILIAR & Respeito/seriedade (11 ocorrências); \\
& Moradia/lar (04 ocorrências); \\
& Descanso (02 ocorrências); \\
& Conforto (02 ocorrências); \\
& Melhor lugar/ nada substitui; \\
& Perfeito; \\
& Fortaleza; \\
& Melhor; \\
& Minha casa é religiosa; \\
& É o núcleo de descanso, local para um maior convívio pessoal e \\
& familiar; \\
& Lazer; \\
\hline COTIDIANO & Rotina (03 ocorrências); \\
& Sem emoção; \\
& Somente com a esposa; \\
\hline
\end{tabular}




\begin{tabular}{|l|l|}
\hline FALTA DE & $\begin{array}{l}\text { Falta de liberdade (05 ocorrências); } \\
\text { Pemos a convicção de que a qualquer hora poderemos ser } \\
\text { surpreendidos nas horas mais inconvenientes; } \\
\text { Minha casa a esposa não aceita dependendo do que eu quero } \\
\text { fazer por causa das crianças; }\end{array}$ \\
\hline OUTROS & $\begin{array}{l}\text { Não se paga (02 ocorrências); } \\
\text { Ambos são confortáveis, apenas diferentes. }\end{array}$ \\
\hline
\end{tabular}

c) Depoimento sobre motéis

- Tudo de bom (09 ocorrências);

- Lugar de prazer (06 ocorrências);

- Lugar de fazer amor (03 ocorrências);

- Lugar para fazer o que quer (02 ocorrências);

- Realizar fantasias (02 ocorrências);

- Lugar interessante (02 ocorrências);

- Não ser incomodado;

- Local para encontros;

- Lugar tranqüilo sem preocupação;

- Fazer sexo;

- Segurança e privacidade;

- Quebra de rotina;

- Diferente, com variação de ambientes;

- Ocasião;

- Conforto;

- Felicidade;

- Diversão;

- Para liberar geral;

- Maravilhoso;

- Pecado;

- Ambiente desejado por ter privacidade, com limitações por causa do valor e o prazer e frieza que muitas vezes o local apresenta;

- Um local aconchegante, estimulante, renovador de energias;

- Interessante opção de lazer e diversão; 
- Lugar requintado para desfrutar de grandes momentos de prazer;

- Propício para realizar fantasias e sexo;

- Sedução, magia e sacanagem;

- Diversão com a pessoa amada;

- Um local anti-stress para o ser humano;

- Ficar a vontade e ter prazer até se esgotar;

- Ideal para realizar fantasias em momentos de muito prazer e tesão com uma pessoa especial, sem limites e tempo;

- Atende nossas intenções no quesito imaginação;

- Hoje não é visto como algo profano em que seus freqüentadores são pecadores, mas sim pessoas normais em que estas vão buscar prazer e, até mesmo para mudar a rotina do dia-a-dia;

- Onde a fantasia, intimidade, amor, paixão e realização se executam com maior intimidade;

- Local para divertimento entre casais para uma quebra de rotina;

- Lugar no qual tenho liberdade de estar exercitando o meu outro lado

- Um local onde fazem algo que poderia ser feito em outro lugar, com maior comodidade, mesmo com pessoas certas;

- Um lugar muito gostoso de se freqüentar principalmente quando está amando de verdade, mas sempre procurando saber aquele que te dá condições seguras para ter uma relação agradável e segura. Respeito sempre os direitos e obedecendo a sogra, usa camisinha;

- Quem inventou o motel deveria ser uma pessoa entusiasmada, de bem com a vida, pois para inventar um lugar tão impressionante, um lugar realmente bom para desfrutar o prazer.

A análise da frequêencia, semelhanças e proximidades semânticas das diversas evocações/associações feitas pelos sujeitos masculinos levam a construção dos seguintes campos semânticos: em relação à sexualidade: sexo/prazer/fantasia; em relação caráter reservado: privacidade/tranqüilidade; em relação à suspensão do cotidiano: quebra de rotina; em relação ao ambiente físico: conforto/comodidade; e em relação aos aspectos negativos: imoralidade. 
Intercruzando essas associações a partir das freqüências e categorias identificadas, pode-se dizer que o núcleo central da representação social dos motéis para os sujeitos masculinos é: sexo/prazer e privacidade/quebra de rotina.

Em relação à palavra casa, percebe-se um sentimento de pertencimento, convivência e comunhão muito forte, como se supôs na hipótese. O lar é como um porto seguro que como tal, é sacralizado, consciente e/ou inconscientemente nos atos e cuidados praticados na sua cotidianidade. As evocações apresentadas permitiram identificar os seguintes campos semânticos: familiar/respeito, rotina/falta de liberdade.

Quando questionados sobre a possibilidade de permitir que os filhos levem parceiros para dormirem juntos em casa, percebe-se uma resistência a essa idéia por parte de $52,7 \%$ dos entrevistados e entre os que permitiram por parte dos filhos é o dobro $(32,43 \%)$ dos que permitiram por parte das filhas mulheres $(18,91 \%)$, o que reforça a presença do conservadorismo nos lugares de gênero, por parte dos entrevistados.

NOLASCO $^{36}$ afirma que no campo da sexualidade, o homem, portanto, entra nesse mundo como objeto de entretenimento. A sexualidade, tal e qual conhecemos tradicionalmente, não tem mais sentido nesse mundo regulado pela tecnologia. Nem como força, vigor ou expressão da natureza; essa colocação só vem a reforçar as mudanças sociais desde a década de 50 até os tempos atuais vem transformando as representações sociais tanto da mulher, quanto do homem no campo da sexualidade.

É nesse campo das representações sociais que os motéis nos moldes brasileiros entram como um local destinado a encontros reservados, que propicia a liberdade que muitas vezes não se tem em casa e com isso acaba por proporcionar também uma suspensão do cotidiano no que se refere à sexualidade.

\subsubsection{Representação Social para o Sujeito Feminino}

\footnotetext{
${ }^{36}$ NOLASCO, Sócrates. A violência é masculina. Revista Isto É. www.garef.com.br/painel. Acesso: 23/11/2003.
} 
Gráfico 22

O Que Chama a Atenção no Motel

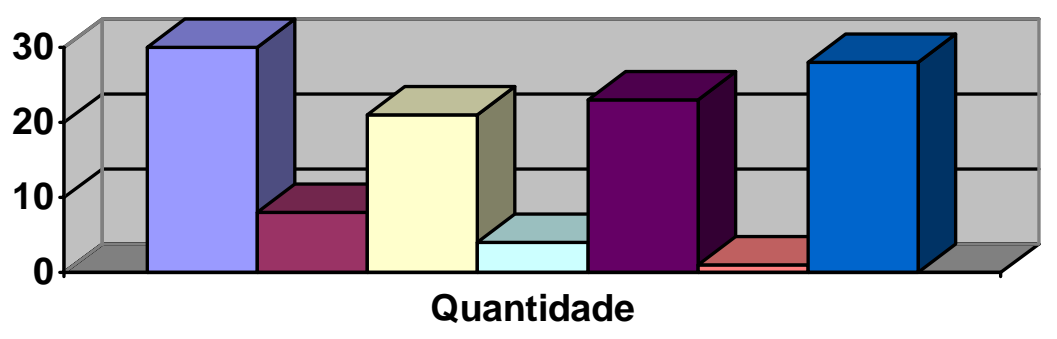

$\square$ privacidade

mudança de ambiente

$\square$ decoração

variedade de ambientes oferecidos

não respondeu

$\square$ mistério

Fonte: pesquisa realizada pela autora no período de setembro e outubro/2003.

A relação aqui apresentada é proporcional aos 100\% da amostragem, pois algumas das entrevistadas que, mesmo tendo declarado não freqüentarem motel optaram por responder, em função já terem ido ou irem eventualmente a motéis.

Quando questionadas sobre o que mais chama a atenção no ambiente de motel, 37,5\% da amostra feminina apontam a privacidade como o principal elemento; seguido pela variedade de ambientes oferecidos com 28,75\%; já a mudança de ambiente também chama a atenção de 26,25\%; seguida da decoração que chama a atenção de $10 \%$ das mulheres; o ar de mistério desperta a atenção de 5\% das entrevistadas; somente $1,25 \%$ apontaram outros motivos; e $35 \%$ não responderam. Tanto quanto para os homens o caráter privativo dos motéis é os fatos mais atrativos, bem como a variedade de ambientes, que por sua vez são elementos que mais distanciam o ambiente do motel, da casa, ou dos quartos nas casas dos entrevistados. 
Gráfico 23

Qual o Significado do Motel

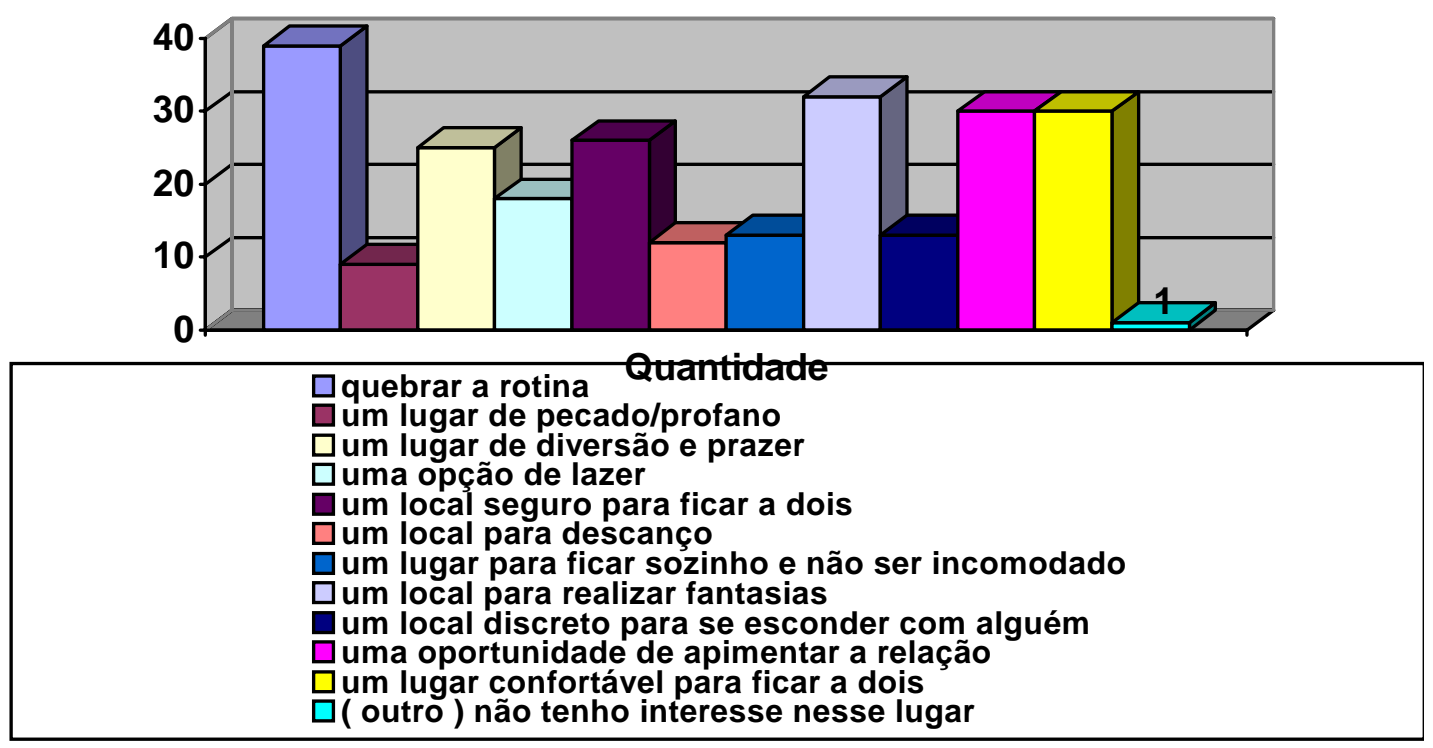

Fonte: pesquisa realizada pela autora no período de setembro e outubro/2003.

Pelo fato da questão ser de múltipla escolha a somatória dos percentuais ultrapassa os $100 \%$, ou seja, o motel pode ter mais de um significado para uma mesma pessoal.

Para 48,75\% do sujeito feminino os motéis representam uma quebra de rotina; seguido de $40 \%$ que vêem os motéis como um local para se realizar fantasias; para 37,5\% os motéis significam uma oportunidade de apimentar a relação, e para outros 37,5\% das entrevistadas é um local confortável para ficar a dois; 32,5\% vêem os motéis como um seguro para ficar a dois; 31,25\% vêem os motéis como local de diversão e prazer; para 22,5\% das entrevistadas os motéis significam uma opção de lazer; $16,25 \%$ apontaram os motéis como um lugar para ficar sozinho e não ser incomodado; e outros 16,25\% já vêem os motéis como um local discreto para se ficar a dois; $15 \%$ acham que o motel é um local para descanso; 11,25\% o motel tem significado negativo, ou seja, representa um local de pecado/profano; e 1,25\% apontou outro motivo, alegando não ter interesse nenhum nesse lugar. O que vem a confirmar a hipótese de que os motéis representam uma suspensa do cotidiano para as mulheres. 
Gráfico 24

Se você tem ou tivesse filho(a) jovem permitira que:

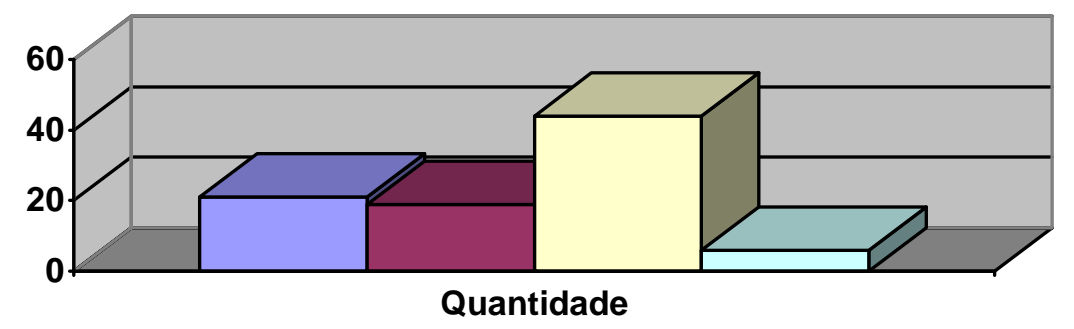

$\square$ Seu filho trouxesse a namorada para dormirem juntos na sua casa

口Sua filha trouxesse a namorada para dormirem juntos na sua casa

$\square$ Não permitira que nem filho e nem filha trouxessem namorado(a) para dormirem juntos na sua casa

$\square$ não responderam

Fonte: pesquisa realizada pela autora no período de setembro e outubro/2003.

Quando questionadas sobre a aceitação de que os filhos(as) levem seus namorados(as) para dormirem juntos em suas casas, o gráfico 24 demonstra que, $55 \%$ dos entrevistados não permitiram que seus filhos(as) levassem namorados(as) para dormirem em casa; 26,25\% permitiram que apenas os filhos (homens) levassem namoradas para dormirem juntos em casa; e ao contrário dos homens entrevistados, quase a mesma quantidade, $23,75 \%$ permitiriam que suas filhas (mulheres) levassem seus namorados para dormirem em casa; e 7,5\% das entrevistadas não responderam. Apesar do público feminino apresentar maior flexibilidade em relação às filhas, ainda assim percebe-se que o conservadorismo não é exclusividade do público masculinos, as mulheres ainda se apresentam bastante conservadoras.

\section{- Questões Abertas}

Assim como na análise do sujeito masculino, a estrutura está padronizada a partir das categorias identificadas em função da associação semântica e semelhanças definindo grupos respectivamente. 
a) Quando pensa na palavra MOTEL, qual a primeira coisa que vem a sua cabeça? :

\begin{tabular}{|c|c|}
\hline SEXUALIDADE & $\begin{array}{l}\text { Prazer e diversão ( } 21 \text { ocorrências); } \\
\text { Sexo (15 ocorrências); } \\
\text { Amor (08 ocorrências); } \\
\text { Fantasias (05 ocorrências); } \\
\text { Sedução e sexo além dos limites (02 ocorrências); } \\
\text { Liberdade sexual (02 ocorrências); } \\
\text { Vários tipos de prazer; } \\
\text { Sexo e putaria; } \\
\text { Encontros amorosos; } \\
\text { Transar diferente; } \\
\text { Sedução e amor; } \\
\text { Camisinha (em motel tem que usar). }\end{array}$ \\
\hline $\begin{array}{l}\text { CARÁTER } \\
\text { RESERVADO }\end{array}$ & $\begin{array}{l}\text { Privacidade e tranqüilidade (07 ocorrências); } \\
\text { Tranqüilidade e total intimidade; } \\
\text { Não ser interrompido por ninguém; } \\
\text { Local de privacidade para pessoas que tem atração sexual e } \\
\text { responsabilidade familiar; } \\
\text { Lugar para estar a dois; } \\
\text { Lugar para esconder dos pais; } \\
\text { Encontros escondidos; } \\
\text { Não ser interrompida; } \\
\text { Privacidade e liberdade. }\end{array}$ \\
\hline $\begin{array}{l}\text { SUSPENSÃO } \\
\text { DO } \\
\text { COTIDIANO }\end{array}$ & $\begin{array}{l}\text { Quebra de rotina (08 ocorrências); } \\
\text { Momento de lazer; } \\
\text { Lazer e diversão. }\end{array}$ \\
\hline $\begin{array}{l}\text { AMBIENTE } \\
\text { FÍSICO }\end{array}$ & $\begin{array}{l}\text { Lugar lindo; } \\
\text { Lugar bonito, aconchegante, gostoso, cozinha legal, um lugar de } \\
\text { prazer e mais discreto e higiene; } \\
\text { Lugar tranqüilo, confortável e pode ser cheio de realizações; } \\
\text { Segurança e tranqüilidade; } \\
\text { Lugar bonito, romântico e tranqüilo; } \\
\text { Lugar ousado; } \\
\text { Conforto e privacidade. }\end{array}$ \\
\hline $\begin{array}{l}\text { ASPECTOS } \\
\text { NEGATIVOS }\end{array}$ & $\begin{array}{l}\text { Traição (02 ocorrências); } \\
\text { Lugar profano e cheio de pecado (02 ocorrências). }\end{array}$ \\
\hline
\end{tabular}

\section{b) Fazendo uma comparação entre o motel e a sua casa como classificaria cada um deles?}


Nos resultados da comparação livre entre os ambientes da casa e do motel realizadas pelo sujeito feminino, assim como na análise dos sujeitos masculino, pode-se manter as mesmas categorias tanto para associação livre com a palavra motel, quanto para a palavra casa.

\begin{tabular}{|l|l|}
\hline \multicolumn{1}{|c|}{ MOTEL } \\
\hline SEXUALIDADE & Fantasia (13 ocorrências); \\
& Prazer (04 ocorrências); \\
& Diversão (03 ocorrências); \\
& Local para fazer amor (03 ocorrências); \\
& Local para fazer sexo (02 ocorrências); \\
& Descontração (02 ocorrências); \\
& Realização de desejos; \\
& Liberação; \\
& Romantismo e sedução; \\
& Tudo de bom (muita farra e curtição); \\
& Local para encontro amoroso; \\
& Intimidade; \\
& Aventura, paixão e loucura; \\
& Novidade, sedução, convite ao prazer; \\
& Intimidade apimentada. \\
\hline CARÁTER & Privacidade (10 ocorrências); \\
RESERVADO & Liberdade (06 ocorrências). \\
\hline SUSPENSÃO & Quebra de rotina (12 ocorrências); \\
DO & Novidade (02 ocorrências); \\
COTIDIANO & Descanso; \\
& Não precisa ter moral; \\
& Lugar para fazer o que não faço em casa; \\
FÍSICO & Mistério; \\
\hline Loucura; & Novidade, descoberta; \\
& Fuga, busca do diferente, novo. \\
& Local mais excitante (02 ocorrências); \\
Comodidade e liberdade; \\
Nota 10 por causa da hidro; \\
Aconchegante; \\
Segurança. \\
\hline Grande fonte de contaminação (02 ocorrências); \\
Lugar cheio de doenças; \\
Sujeira. \\
\hline
\end{tabular}

\section{CASA}




\begin{tabular}{|l|l|}
\hline COTIDIANO & Rotina (13 ocorrências); \\
& Lugar comum; \\
& Privacidade e monotonia; \\
& Rotina e sexo morno; \\
& Rotina e não estimulante. \\
\hline SAGRADO / & Respeito (09 ocorrências); \\
FAMILIAR & Familiar (07 ocorrências); \\
& Amor (04 ocorrências); \\
& Moradia/lar (03 ocorrências); \\
& Lugar sagrado, respeito aos filhos e vizinho (03 ocorrências); \\
& Cantinho preferido \\
& Privacidade e segurança; \\
& Local aconchegante e familiar; \\
& Nada melhor que minha casa; \\
& Em casa sou a rainha; \\
Ambiente gostoso há mil maneiras de movimentar a relação; & Conforto; \\
Lugar de conforto e amor, vibração de amor puro; \\
Meditação e religiosidade; \\
Meu paraíso; \\
Segurança e higiene; \\
Lugar de paz; \\
Lar, família e amor; \\
Muito pessoal; \\
Meu lugar, liberdade, momentâneo.
\end{tabular}

\section{c) Depoimentos sobre motel:}

- Sair da rotina com a pessoa amada (09 ocorrências);

- Privacidade (06 ocorrências);

- Um local onde as pessoas liberam a imaginação (03 ocorrências);

- Tudo de bom (03 ocorrências);

- Lugar para divertir e buscar prazer (03 ocorrências);

- Lugar para realizar fantasias (03 ocorrências); 
- Local para fazer amor (02 ocorrências);

- Há vários motéis onde há privacidade, outros não. É chato você ver na propaganda uma coisa e chegar lá e é outra bem diferente. Para mim o motel confortável é que não engana ninguém é aquele que raramente você vê propaganda, esses são caros, mas vale a pena;

- Para quem gosta deve ser bom, para mim não é certo;

- Um lugar tranqüilo, agradável para ficar a dois, entre quatro paredes;

- Momento de amor, troca de carinho;

- Um ambiente que eu particularmente gosto muito, é um lugar tranqüilo, com ambientes variados e que em quatro paredes podemos estar fazendo coisas que em outro lugar estaria intimidados, enfim e como sexo é muito bom é preciso estar confortavelmente bem instalados;

- Não é o meu forte por ser um lugar com horário programado. Você vai ali apenas para satisfazer-se como se fosse um objeto de desejo;

- Lugar muito impessoal, com cheiro, cores diferentes, que muitas vezes não agrada;

- Lugar diferente para comemorações, mudança de rotina, diversão e prazer;

- Um lugar onde eu vou sair da rotina, sossegado, sem filhos incomodando, boa comida, e ainda encontro um conjunto de coisas que me levará a um prazer. É uma noite especial, que a gente sempre guarda no coração;

- Lugar para fazer coisas privadas;

- Um local aonde várias pessoas vai tanto para sair da rotina, quanto para satisfazerem o ego animal;

- Pecado;

- Gostoso dependendo da companhia;

- Lugar aconchegante, seguro, reservado, caro (se quiser coisa boa);

- Local onde tenho privacidade e tranqüilidade para as minhas vontades e imaginação; 
- Para alguns é uma realização de fantasia, sair escondido para satisfazer o que não consegue em casa;

- Infelizmente muitas pessoas vão escondidas por serem casados ou outros vão por curiosidade ou até para quebrar a rotina do casal;

- É necessário, não é imoral;

- É um lugar onde os casais encontram para fugir da rotina, descansar, realizar suas fantasias, diversão e prazer; porém não deve ser utilizado para fugir das frustrações ou como um santo remédio para tratar de um problema conjugal;

- Nunca fui, mas deve ser muito bom;

- É ótimo, mas perigoso para quem acha que é apenas lugar para sexo;

- Quando não há outra opção é seguro e oferece uma diversidade que não se tem em casa;

- Lugar seguro;

- Meu esposo nunca me levou, mas tenho vontade de ir;

- Lugar de muito carinho;

- Higiene e limpeza desses locais são perigosas;

- Independente do estado civil ou opção sexual, todos deveriam freqüentar motel, pois com certeza seriam mais felizes e realizariam suas fantasias sexuais;

- É um lugar comum como outro qualquer, só que a gente fica mais à vontade para fazer o que quer;

- Lugar onde os casais se encontram para uma noite de sexo, fantasia e também é considerado um lugar proibido;

- É um lugar muito bom, é marcante, excitante, gostoso e traz satisfação;

- Um lugar onde se pode aproveitar os momentos mais carinhosos e particulares de uma forma mais proveitosa;

- Nunca fui, mas desejo ir, conhecer, e quem sabe, freqüentar mais vezes. 
$\mathrm{Na}$ análise do sujeito feminino percebeu-se uma grande semelhança entre a freqüência e proximidades semânticas das diversas evocações/associações realizadas pelos sujeitos masculinos em relação à Representação Social dos Motéis. Identificouse a construção dos seguintes campos semânticos: em relação à sexualidade: sexo/prazer/fantasia; em relação caráter reservado: privacidade/tranqüilidade; em relação à suspensão do cotidiano: quebra de rotina; já em relação ao ambiente físico: conforto/beleza; e em relação aos aspectos negativos: traição/pecado e contaminação-doença.

Intercruzando essas associações a partir das freqüências e categorias identificadas, pode-se dizer que o núcleo central da representação social dos motéis para os sujeitos femininos é: prazer/fantasia e privacidade/quebra de rotina e para uma pequena parcela: pecado/doença.

Em relação à palavra casa, percebe-se um sentimento de pertencimento amoroso, porém a rotina apresenta um peso maior de compromisso e envolvimento, denotando uma maior obrigatoriedade comum a tradicional idéia mulher/mãe/lar. O lar é ainda o espaço rotineiro da mulher, o respeito sempre ligado aos filhos e os vizinhos. As evocações apresentadas permitiram identificar os seguintes campos semânticos: familiar/respeito, rotina/monotonia e falta de privacidade.

A possibilidade de permitir que os filhos levem parceiros para dormirem juntos em casa ainda é bem restrita, 55\% das entrevistadas rejeitam essa idéia não aceitando o fato. Já entre as mulheres que aceitariam que os filhos levassem parceiros(as) para dentro de casa, houve maior equilíbrio, 26,25\% das entrevistadas permitiriam que os filhos homens o fizessem e 23,75\% permitiram que as filhas mulheres levassem parceiros ra dormirem juntos em casa. Aqui se percebe uma maior flexibilidade da mulher em relação às filhas.

\subsubsection{Análise Comparativa das Representações Sociais dos Sujeitos}

Apesar de ter apresentado expressiva diferença no hábito de utilização dos motéis, bem como da freqüência em termos de quantidade, constatou-se que, para 
ambas as categorias de sujeito, a representação social desse ambientes é muito próxima. Quando questionados sobre o que mais chama a atenção no motel, tanto para os homens, quanto para mulheres, os três elementos que se destacaram foram: privacidade, variedade de ambientes, mudança de ambiente, respectivamente. Todos esses elementos são marcantes, pois remete a quebra de rotina/privacidade elemento fundamental na representação social dos motéis.

Em relação ao significado, pode-se destacar os três elementos principais: quebra de rotina, o elemento mais recorrente tanto para homens quanto para mulheres apontam, novamente como principal significado a possibilidade de quebra de rotina; posteriormente os itens prazer/diversão e fantasia, se alternam para homens e mulheres, sendo a fantasia o segundo recorrente em termos de representação e prazer/diversão em terceiro lugar, invertendo-se essa ordem nas representações masculinas.

Em nenhum momento na pesquisa o motel aparece como meio de hospedagem e sim como um local profano, mas não no sentido de pecado em oposição ao espaço sagrado do lar, mas como elemento que propicia uma suspensão do cotidiano, sendo que a utilização do motel, vem no sentido de quebra de rotina, de liberdade e privacidade que o espaço do lar restringe. Essa restrição tanto se dá pela presença de familiares, condições de moradia e etc; quanto pelo próprio conservadorismo, ainda com pitadas de machismo, compartilhado por homens e mulheres. A casa se configura num local de respeito, onde deve se guardar os bons costumes, até o sexo, como citado por ambos os sujeitos é muitas vezes, contido, morno, rápido e com restrições.

Esse caráter conservador é percebido também na criação dos filhos, onde a maioria absoluta de homens e mulheres ainda não vê com bons olhos a possibilidade de seus filhos e filhas levarem para dentro de casa, namorados e namorados para dormirem juntos. Entre o sujeito feminino que aceita, se vê um equilíbrio maior entre as que aceitam os filhos e as que aceitam as filhas levarem acompanhantes para dentro de caso; ao contrário dos homens entrevistados, que demonstram ainda bastante machismo em relação ao assunto, pois entre os homens que aceitariam que os filhos levassem namoradas para casa, somente a metade desse percentual aceitaria que suas filhas levassem namorados em casa. 
Nesse contexto pode inferir que o homem é mais conservador reproduzindo o senso comum, de que o filho pode porque é homem e as filhas, por serem mulheres devem se dar ao respeito. Já em relação às mulheres, percebe-se uma flexibilização em relação às filhas ou até mesmo uma certa cumplicidade feminina. .

Partindo do pressuposto de que a representação social da casa, no que se refere à sexualidade, é um dos componentes do contexto do núcleo central da representação dos motéis para a população adulta no Brasil, na atualidade, está construída em cima da suspensão do cotidiano, como uma complementação bem vinda, na maioria dos casos, que possibilita uma revitalização da sexualidade, com se percebe nos campos semânticos identificados, a partir do cruzamento dos campos semânticos construídos pelos sujeitos masculinos e femininos, em primeiro lugar: privacidade/quebra de rotina, e em segundo lugar: prazer/sexo/fantasia.

Importante destacar que esses elementos, constantes nos discursos dos sujeitos, reforçam e acentuam a característica de forte erotismo presente na cultura do povo brasileiro, que por sua vez vem reforçar o conjunto de fatores que motivaram a transformação dos motéis brasileiros em locais destinados a encontros reservados e não meio de hospedagem para turista rodoviário como ocorre praticamente no restante do mundo. 


\section{CONSIDERAÇÕES FINAIS}

Aprofundar o estudo dos motéis nos moldes em que foi construído no Brasil é um desafio que vem descortinando novas facetas da cultura, da sexualidade e dos hábitos desse povo tão singular e único, como coloca o antropólogo Roberto Damatta e com o qual concorda-se plenamente.

O motel brasileiro é também, singular, pelo fato de apresentar uma ressignificação da utilização desses locais, diferenciada dos significados para outros povos existentes no restante do mundo. Isso se dá, não só pela alta rotatividade comum a esses empreendimentos, pois isso acontece em outros lugares como no Uruguai, e sim, por um conjunto de características de ambientação, do caráter sigiloso e reservado, do sentido de suspensão da rotina, que faz com que esses ambientes, ao invés de cumprirem o papel de meio de hospedagem, assumem o papel de espaço de entretenimento que proporciona lazer e diversão no campo da sexualidade, como fica claro na representação identificada no campo semântico: prazer/sexo/fantasia.

Ainda se percebe um forte conservadorismo, principalmente na representação social do homem, o qual coloca a casa como ambiente de respeito, familiar, gerando comportamento contido com a família e por parte da família. As mulheres ainda reproduzem esse conservadorismo, quando evocam a categoria de familiar/respeito; porém com menor diferença entre a permissibilidade para filhos e filhas, ou seja, as mães menos discriminatórias para as filhas do que os pais.

Os motéis podem ser identificados como o espaço que permite a transposição da esfera do familiar/respeito para a esfera do prazer/sexo/fantasia no sentido de que esse ambiente permite e proporciona a quebra de rotina/privacidade, apontando o elemento que complementa a tríade da representação social do brasileiro a respeito dos motéis.

A partir dessas constatações pode-se comprovar a hipótese de que os motéis no Brasil são locais para encontros reservados em função dos padrões ligados à 
Representação Social da casa no que tange a sexualidade, sendo que à visão desta ainda como espaço sagrado, o espaço da família, da convivência e do descanso, principalmente para os homens e no qual deve-se guardar respeito e desvelo.

Em relação à hipótese de que o imaginário que o brasileiro faz sobre os motéis é de lugar profano contrário ao espaço, ainda, sagrado do lar, comprova-se apenas parcialmente, uma vez que ficou claro que a casa é realmente um espaço sagrado, porém pode-se inferir que o motel como profano apresenta uma ressignificação, uma vez que é profano não no sentido de pecaminoso e ruim para a maioria dos entrevistados, mas profano, no sentido de público, de liberdade e de libertinagem, de ser o outro lado da moeda, como coloca Damatta, o que não é permitido em casa como o trabalho e o sexo - se tem na rua, e nesse sentido, hoje em dia o motel não e oposição, mas um lugar complementar no exercício da sexualidade. Somente para uma pequena minoria que chega a 10\% o motel é um lugar representado como profano, com o sentido de pecaminoso, sujo e imoral.

Nesse processo de familiarização do motel, ancorado no exercício da sexualidade, mesmo estando o sujeito feminino inserido em espaço social concreto que continuam reproduzindo as representações sociais conservadoras com algumas características machistas, comprovou-se que a representação dos motéis realmente implica na suspensão do cotidiano, porém não só para o sujeito feminino como se pensava, mas também para o sujeito masculino.

Acredita-se, após a finalização provisória desse estudo, que ainda há muito que aprofundar nas pesquisas e reflexões sobre os motéis e seu significado. Há necessidade de uma investigação profunda para se descobrir o início da atividade moteleira no país e o conjunto de fatores que levaram a essa transformação do conceito de motéis. Pode, também, ser aprofundado o estudo dessas representações envolvendo o sentido de família/familiar, bem como o fator religiosidade, buscandose identificar qual a influência da opção religiosa nessas representações sociais identificadas. Poder-se-ia analisar as representações sociais desse ambiente para os colaboradores que tem esse ambiente como local de trabalho. Há ainda uma infinidade de abordagens e possibilidades de trabalhos que podem vir a ser desenvolvimentos neste nicho de mercado ainda tão carente de pesquisas e estudos. 


\section{BIBLIOGRAFIA}

ALEXANDRE, Marcos. O sabor popular e sua influência na construção das representações sociais. Em: www. Facha.Edu.Br/publicações/comum. 23/10/2003

ARAÚJO, Emanuel. A arte da sedução: sexualidade feminina na colônia. In DEL

BARBOSA, Sônia M. Costa. A representação da sexualidade e das doenças sexualmente transmissíveis segundo as idosas da Cidade de Olinda - Estudo de Caso na "Cais do Porto"- ONG/Olinda-PE, in: www.naya.org.ar/congresso2002. Acesso em: 8/10/2003.

BANDEIRA, Lourdes e SIQUEIRA, Deis. A perspectiva feminina no pensamento moderno e contemporâneo. In: Revista Sociedade e Estado. Departamento de Sociologia da UNB. Feminino e gênero. Vol. XII, n.2, Brasília, jul-dez/1997.

BASSANEZI, Carla (coord ${ }^{a}$ de textos) História das mulheres no Brasil. São Paulo: Contexto, 1997.

CAMARGO, Luiz Octávio de Lima. Educação para o lazer. São Paulo: Moderna, 1998.

CASTELLI, Geraldo. Administração hoteleira. 7.ed. Caxias do Sul: EDUCS, 2000 Excelência em hotelaria - uma abordagem prática. 3.ed. Rio de Janeiro: Qualitymark, 2000.

Centro de Apoio Hoteleiro. Motel, organize e administre. Campinas/SP, Ipê, 2000.

DEL PRIORI, Mary. Ao sul do corpo: condição feminina, maternidade mentalidades no Brasil Colônia. RJ: José Olympio. DF:Edunb, 1993.

(ORG) e BASSANEZI, Carla (coord ${ }^{a}$ de textos). História das

mulheres no Brasil. São Paulo: Contexto, 1997.

. Histórias do cotidiano. São Paulo: Contexto, 2001.

DOMINGUES, Celestino M. Prontuário turístico. 2.ed. Lisboa, INFT, 1997.

DUVEEN, Gerard in MOSCOVICI, Serge. Representações sociais: investigações em psicologia social. Editado em inglês por Gerard Duveen; traduzido do inglês por Pedrinho A Guareschi. Petrópolis/RJ: Vozes, 2003. 
FOUCAULT, Michel. História da sexualidade 2 : o uso dos prazeres._Tradução Maria Thereza da Costa Albuquerque e J.A. Guillon Albuquerque. R.J: d. Graal, 1984.

LATTIN, Gerald W. Administración moderna de hoteles y moteles. México: Trillas, 1975 (reimp.2000)

MORIN, Edgar. Cultura de massas no século XX: necrose._3.ed. Rio de Janeiro: Forense Universitária, 1999.

MOSCOVICI, Serge. Representações sociais: investigações em psicologia social. Editado em inglês por Gerard Duveen; traduzido do inglês por Pedrinho A Guareschi. Petropólis/RJ: Vozes, 2003.

MOTT, Luiz. Cotidiano e vivência religiosa: entre a capela e o calundu. In: NOGUEIRA, Isildinha B. O corpo da mulher negra. Em: www.estado gerais.org. Acesso em: 23/10/2003.

NOLASCO, Sócrates. A violência é masculina. Revista Isto É. Em: www.garef.com.br/painel_01_08_10 html. Acesso em: 23/10/2003.

PROST, Antoine e VINCENT, Gerard (orgs), tradução: Denise Butmann. História da vida privada 5: da primeira Guerra a nossos dias. São Paulo: Companhia das Letras, 1992.

RAMOS, Jucelem G. Belchior. A representação social da mulher construída na relação conjugal violenta na Cidade de Manaus. Em: www.rizoma.ufsc.br/semint/trabalho. Acesso em: 19/11/2003.

Revista Sociedade e Estado. Departamento de Sociologia da UNB. Feminino e gênero. Vol. XII, n.2, Brasília, jul-dez/1997.

RIBEIRO, Darcy. O povo brasileiro: evolução e o sentido do Brasil. São Paulo: Companhia das Letras, 1995. 
ROMANELLI, Ronaldo. Eva Tubinambá. In DEL PRIORI, Mary (org) e SAMARA , Eni de Mesquita. A família brasileira. SP, Brasiliense, 1983

SEGATO, Rita Laura. Os percursos do gênero na antropologia e para além dela. In: Revista Sociedade e Estado. Departamento de Sociologia da UNB. Feminino e gênero. Vol. XII, n.2, Brasília, jul-dez/1997

SOIBET, Rachel. Mulheres pobres e violência no Brasil urbano. In: DEL PRIORI, MARY (ORG) e BASSANEZI, Carla (coord de textos). História das mulheres no Brasil. São Paulo: Contexto, 1997.

SOUZA, Laura de Mello e. (org) História da vida privada no Brasil 1: cotidiano e vida priva na América Portuguesa. São Paulo: Cia. Das Letras, 1997.

VACCARI, Vera. Mitos e tabus sobre a sexualidade. Em: www.veravaccari.psc.br/leiturareflexao_mitos.php. Acesso em: 23/09/2003.

VAINFAS, Ronaldo. Moralidade brasílicas: deleites sexuais e linguagem erótica na sociedade escravista. In SOUZA, Laura de Mello e. (org) História da vida privada no Brasil 1: cotidiano e vida priva na América Portuguesa. São Paulo: Cia. Das Letras, 1997. 